\title{
Targeting perennial vegetation in agricultural landscapes for enhancing ecosystem services
}

\author{
H. Asbjornsen ${ }^{1,2 \star}$, V. Hernandez-Santana ${ }^{1,2,3}$, M. Liebman ${ }^{4}$, J. Bayala ${ }^{5}$, J. Chen ${ }^{6}$, M. Helmers ${ }^{7}$, \\ C.K. Ong ${ }^{8}$ and L.A. Schulte ${ }^{1 \dagger}$ \\ ${ }^{1}$ Department of Natural Resources and the Environment, University of New Hampshire, Durham, NH 03824 , \\ USA. \\ ${ }^{2}$ Department of Natural Resource Ecology and Management, lowa State University, Ames, IA 50011, USA. \\ ${ }^{3}$ IRNAS CSIC, Instituto de Recursos Naturales y Agrobiologia, Seville 41080, Spain. \\ ${ }^{4}$ Department of Agronomy, lowa State University, Ames, IA 50011, USA. \\ ${ }^{5}$ World Agroforestry Centre (ICRAF), ICRAF-WCA/Sahel Node, BP E5118 Bamako, Mali. \\ ${ }^{6}$ Department of Environmental Sciences, University of Toledo, Toledo, OH, 43606-3390, USA. \\ ${ }^{7}$ Department Agricultural and Biosystems Engineering, lowa State University, Ames, IA 50011, USA. \\ ${ }^{8}$ World Agroforestry Centre, 30677, Nairobi, Kenya. \\ ${ }^{*}$ Corresponding author: heidi.asbjornsen@unh.edu
}

\begin{abstract}
Over the past century, agricultural landscapes worldwide have increasingly been managed for the primary purpose of producing food, while other diverse ecosystem services potentially available from these landscapes have often been undervalued and diminished. The incorporation of relatively small amounts of perennial vegetation in strategic locations within agricultural landscapes dominated by annual crops - or perennialization — creates an opportunity for enhancing the provision of a wide range of goods and services to society, such as water purification, hydrologic regulation, pollination services, control of pest and pathogen populations, diverse food and fuel products, and greater resilience to climate change and extreme disturbances, while at the same time improving the sustainability of food production. This paper synthesizes the current scientific theory and evidence for the role of perennial plants in balancing conservation with agricultural production, focusing on the Midwestern USA as a model system, while also drawing comparisons with other climatically diverse regions of the world. Particular emphasis is given to identifying promising opportunities for advancement and critical gaps in our knowledge related to purposefully integrating perennial vegetation into agroecosystems as a management tool for maximizing multiple benefits to society.
\end{abstract}

Key words: biodiversity, ecosystem services, perennial plants, resilience, sustainable agriculture

\section{Introduction}

With the intensification of global food production, agricultural strategies have increasingly emphasized maximizing crop yields, often at the expense of other ecosystem services $(\mathrm{ES})^{1}$. This has been accomplished, in part, by replacing the original native vegetation with simplified systems dominated by a single or a few crop species, and by favoring annual over perennial species.

$\dagger$ Co-authors are listed alphabetically after the third co-author to reflect their equal contributions to the manuscript.
Although this trend has led to the more than doubling of global food production since the $1950 \mathrm{~s}^{2}$, maintaining these productivity levels over time demands large amounts of external inputs such as fertilizers, pesticides, irrigation and fossil fuels ${ }^{3}$. Concomitantly, many of the ES provided by diverse, native plant communitiesincluding regulating (e.g., water supply and quality, climate and pest control), supporting (nutrient cycling, soil formation and pollination), and cultural (spiritual, recreation, education, medicine, etc.) services - are being lost or severely diminished ${ }^{4}$. As the global society increasingly confronts the consequences of these lossesacutely evidenced by expanding hypoxic zones, declining 
water quality, increased incidence of severe flooding and drought, and impoverished biodiversity - there is a growing urgency for developing multifunctional agricultural landscapes that provide diverse ES in addition to provisioning services such as food, fiber, fuel and fodder production $^{5-7}$.

One promising approach to expanding ES provided by agricultural landscapes is through 'perennialization', defined here as the strategic incorporation of diverse perennial plants as integral and purposeful components of agroecosystems to enhance ES benefits. This approach is based on the premise that the positive impacts of perennial plants can be magnified when perennials are targeted to landscape positions that yield disproportionately high ES benefits relative to the land area they occupy. Diverse perennial plant communities have been shown to enhance hydrologic regulation ${ }^{8}$, water quality ${ }^{9}$, carbon sequestration and storage ${ }^{10}$, beneficial organisms for pest control and pollination ${ }^{11}$, soil quality ${ }^{12}$ and biological functioning $^{13}$ relative to simplified cropping systems. Perennial plants can also provide a range of provisioning services to society, including food, fiber, fuel and feed, which can contribute to diversifying production and reducing risk. The societal benefits of perennialization also include cultural and social amenities, as more diverse landscapes can positively impact aesthetic, recreational, tourism and health values within local communities ${ }^{14}$.

Perennialization can also provide a tool for both mitigating and adapting to climate change. Climate change poses a major threat not only to agricultural productivity but also to the capacity of agricultural systems to provide diverse $\mathrm{ES}^{15,16}$. In recent decades, an emphasis of agronomic research has been the development of technologies for maintaining crop yields under future climates, for example, by increasing external inputs, crop breeding or genetic engineering ${ }^{17-19}$. However, these approaches often do not consider the importance of concomitantly sustaining the diverse ES of agricultural landscapes ${ }^{20}$. Increasing the amount of perennial cover in agricultural landscapes generally augments biodiversity, and more diverse ecological communities tend to have greater resilience (the ability to recover rapidly from stress), and stability (the ability to resist change or withstand stress without loss of function), relative to simplified plant communities ${ }^{21}$. Perennialization, by increasing biodiversity of both plants and biological organisms, provides one mechanism for enhancing agroecosystem resilience and stability of cropping systems and their associated ES under climate change ${ }^{22-24}$. With the frequency of extreme events such as drought, flooding, pest infestation and disease predicted to increase under future climates ${ }^{25}$, enhanced resilience and stability will be critical for maintaining the long-term sustainability of food production systems ${ }^{22,26,27}$.

Although multifunctionality of agricultural landscapes is not a new concept ${ }^{5-7}$, studies documenting ES consequences when some portions of agricultural

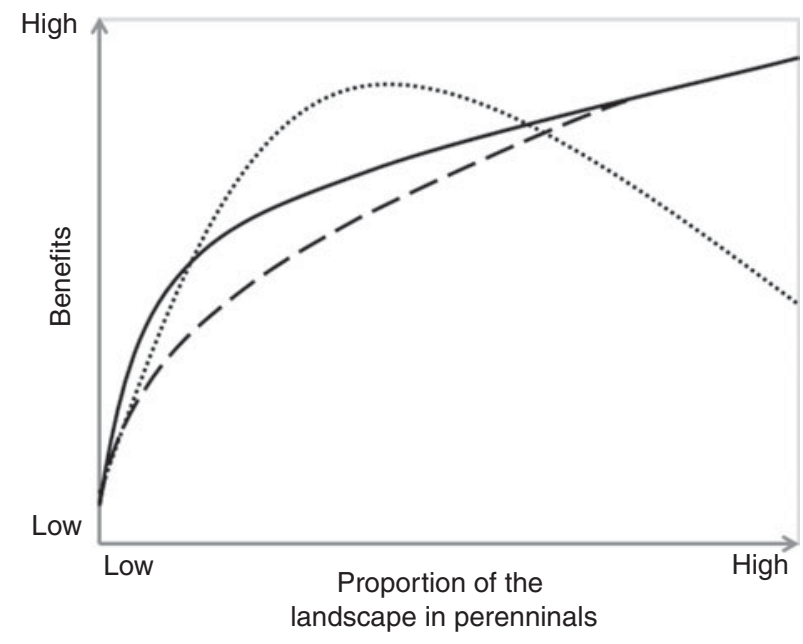

Figure 1. Disproportionate benefits hypothesis: perennial vegetation is expected to produce benefits disproportional to its extent within landscapes; ecosystem benefits of non targeted perennial cover (dashed line), ecosystem benefits of targeted perennial cover (solid line), and socio-economic benefits (dotted line). Examples of ecological benefits include clean water, flood control, pollination, pest suppression and outdoor recreational opportunities. Examples of social benefits include inspiration, connectedness and civic engagement.

landscapes are not utilized to produce food, fiber or fuel, but instead are maintained under perennial vegetation to produce other, less quantifiable or marketable products, are only beginning to emerge ${ }^{28,29}$. In particular, more information is needed about how different types, amounts and locations of perennial cover influence the cost-benefit tradeoffs of different $\mathrm{ES}^{30-33}$, as well as the policy structures required to facilitate changes in land management practices and market mechanisms ${ }^{31,34}$. Moreover, because areas with perennial vegetation tend to support plant communities having greater species diversity relative to areas managed purely for agricultural crops, teasing apart the relative contributions of perenniality versus biodiversity to the provisioning of different ecosystems services is another challenge in perennialization research requiring greater attention.

In this paper, we argue that redesigning agroecosystems based on perennialization principles can dramatically improve the capacity of agricultural landscapes to provide valuable ES to society, while simultaneously producing sufficient amounts of food, fiber, fuel and bioenergy (Fig. 1). In this paper, we discuss how targeted integration of appropriate mixtures of perennial plants into agricultural landscapes offers a common unifying strategy for augmenting diverse ES, balancing food production with conservation, and enhancing agroecosystem resilience and stability. We focus our discussion on the humid temperate Corn Belt of the Midwestern US, a major global food-producing region accounting for approximately $40 \%$ of the world's total production of corn (Zea mays $)^{35}$. The Corn Belt provides an excellent model 
a)

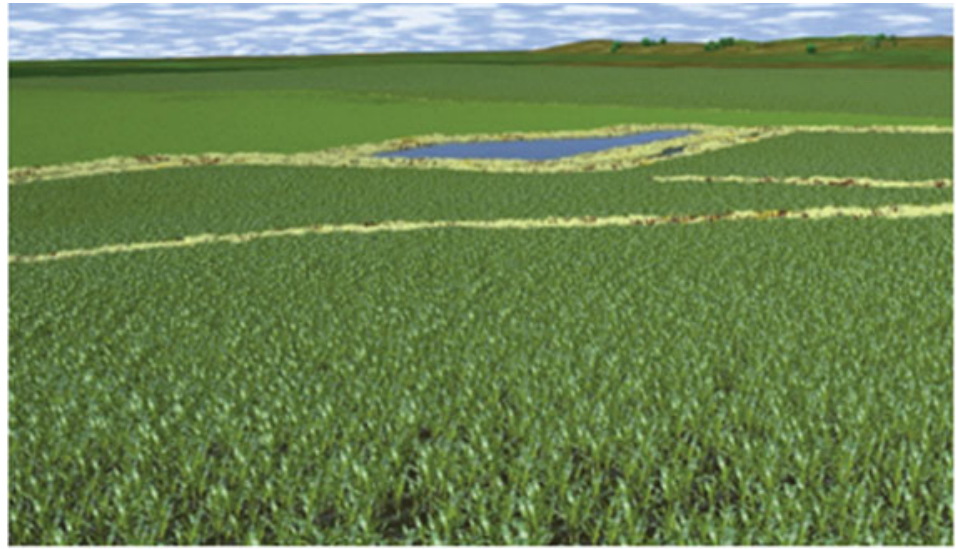

b)

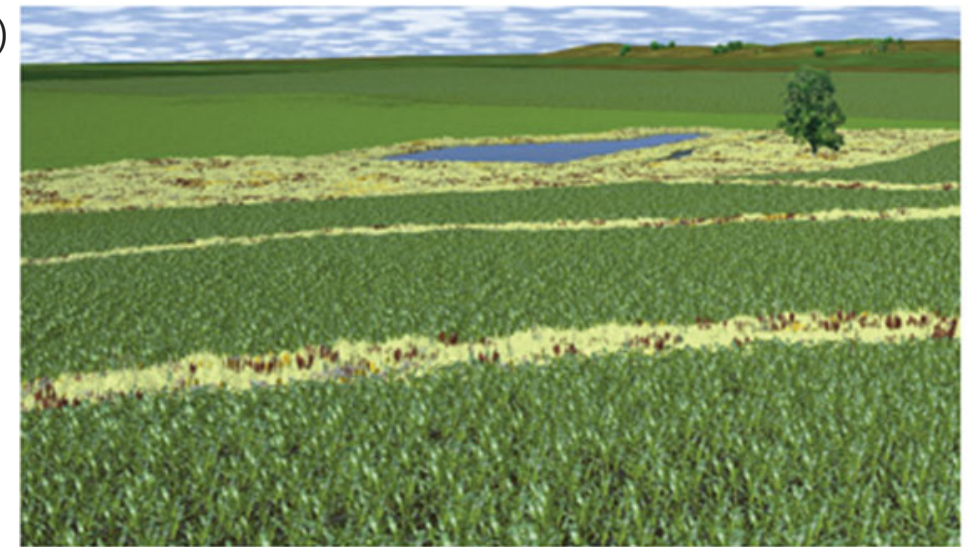

c)

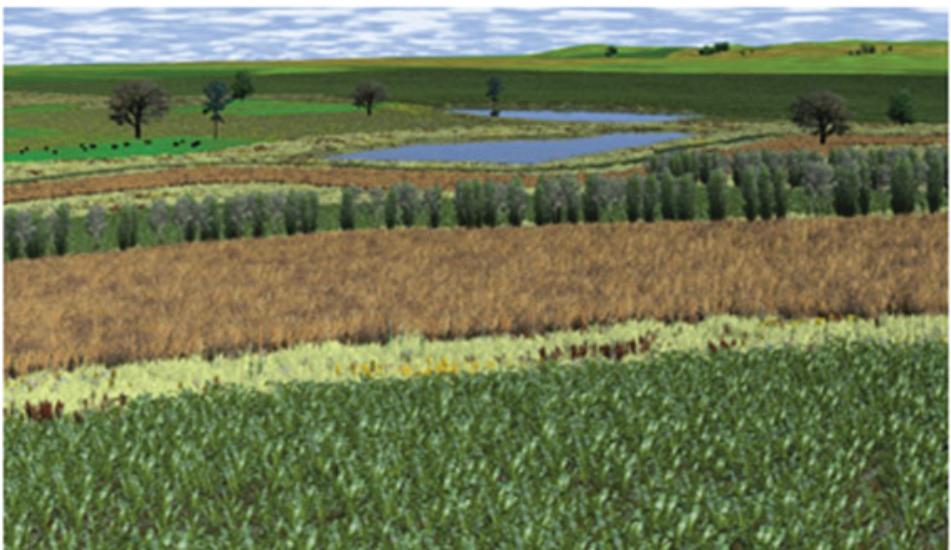

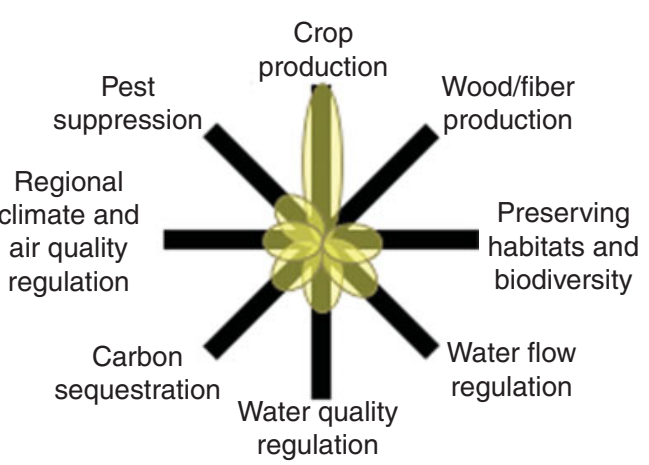
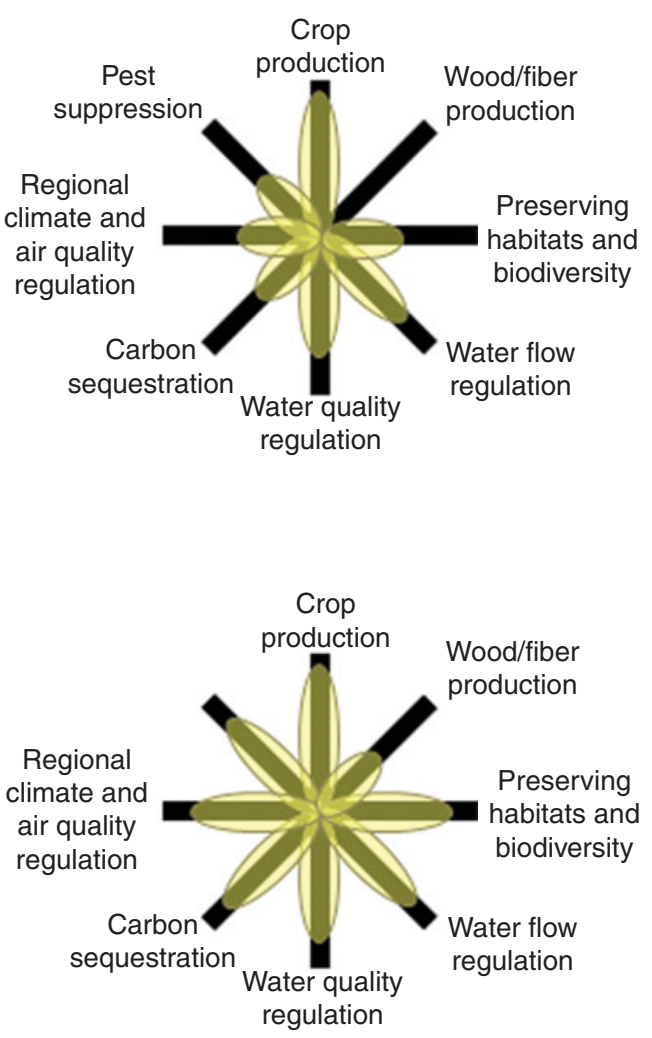

Figure 2. A virtual agricultural landscape with perennial vegetation that is strategically integrated in varying proportions (left) to enhance the delivery of ES, as illustrated in the 'flower' diagrams (right); the proportion of perennial vegetation in each landscape is as follows: (a) $4 \%$, (b) $16 \%$ and (c) $64 \%$.

system for our analysis because it has experienced one of the most pronounced landscape scale conversions worldwide, with $\sim 70 \%$ of the pre-European native grassland vegetation replaced by monocultural annual crops of corn and soybean (Glycine max $)^{36}$. Extensive drainage of natural wetlands together with intensification and mechanization of agricultural practices have accompanied the conversion process ${ }^{37}$. These land-use changes have severely compromised the delivery of fundamental ES to society, such as clean water ${ }^{38,39}$, odor- and toxic-free air $^{40}$, flood control ${ }^{41}$ and wildlife habitat ${ }^{42}$. Despite growing interest over the past several decades in perennial-based conservation practices in the region ${ }^{6}$, a broader valuation of the multiple ES achievable through strategic targeting of perennial vegetation is needed (Fig. 2). We complement our analysis with examples from other regions (e.g., China, Africa and Central America) that have experienced similar trends of agricultural intensification and simplification, and where significant opportunities also exist for better balancing food production and ES through perennialization. Although a detailed global comparative analysis is beyond the scope of this paper, by highlighting 
documented examples where perennialization has contributed on enhancing ES provisioning around the world, we aim to show the broad application of perennialization principles, stimulate cross-country exchange of experiences, and advance new ideas and thinking about future directions of perennialization research.

Given the wide range of potential ES provided by perennialization of agricultural landscapes, we focus our discussion on five ES considered particularly important for sustaining biophysical and human systems: hydrologic regulation and water purification, climate regulation and climate change mitigation, biotic regulation, soil quality and nutrient cycling, and provisioning services. For each ES, we synthesize the current state of knowledge, identify important gaps and research priorities, and consider how mixed perennial-annual agricultural systems in the Midwestern USA compare with other regions in the world.

\section{Hydrologic Regulation and Water Purification}

Declining hydrologic services related to water supply and quality represent a major threat to the well-being of human populations in many regions of the world ${ }^{43}$, and have been directly linked to the expansion of intensively managed annual crops at the expense of diverse perennial vegetation $^{44}$. In the Midwestern US, landscape-scale conversion from perennial to annual crops has resulted in significantly increased streamflow and base flow ${ }^{45}$, increased sediment ${ }^{46}$ and nutrient ${ }^{47}$ delivery to streams, and the formation of hypoxic zones in the Gulf of Mexico $^{48}$.

Perennial plants can restore water purification and flow regulation services to these agriculturally dominated landscapes through several mechanisms. In humid temperate climates such as the Midwestern US, where excess water is often a problem, especially in the early growing season before annual crops have become established, the deeper roots and longer growing season typical of perennial vegetation results in greater total water uptake and evapotranspiration compared with annual crops ${ }^{49,50}$. Additionally, perennial vegetation can improve soil structure and hydraulic properties by increasing the number and size of macropores ${ }^{51-53}$, building organic matter ${ }^{53,54}$ and improving soil porosity ${ }^{55,56}$. Combined, these changes in plant water fluxes and soil properties contribute to greater soil water storage capacity ${ }^{57}$, higher infiltration rates $^{58}$ and reduced runoff ${ }^{59}$. Perennial grasses $^{60,61}$ trees $^{62}$ and tree-grass mixtures ${ }^{63}$ have also been shown to more effectively trap and retain sediment compared with annual crops.

Critical to developing effective perennialization strategies is a sound understanding of how much of the landscape needs to be converted to perennial cover, where such conversions are best located and which species mixtures are most effective. Studies based on both modeling ${ }^{64,65}$ and empirical measurements ${ }^{66,67}$ suggest a nonlinear relationship between the amount of perennial cover and different hydrologic services, resulting in diminishing returns beyond a certain amount. Such nonlinear relationships have been demonstrated for sediment trapping efficiency ${ }^{61,63,68,69}$, retention of nitrogen $(\mathrm{N})$, phosphorus $(\mathrm{P})^{68,70,71}$ and pesticides ${ }^{72}$, and runoff reduction ${ }^{55,56}$. Combined, these findings underscore the notion that relatively small amounts of perennial cover may produce significant ES benefits, while minimizing negative impacts on crop production (Fig. 1).

The location of perennial vegetation in the landscape is critical in determining the lateral and vertical movement of water through watersheds. For example, Sahu and $\mathrm{Gu}^{65}$ used a modeling approach to show that strips occupying $10-20 \%$ of the catchment area were more efficient in reducing $\mathrm{NO}_{3}-\mathrm{N}$ when placed along the contour than along the riparian zone. Jiang et $\mathrm{al}^{73}$ found that perennial plants located on the backslope position showed greater improvement in hydraulic properties compared with summit and footslope positions, suggesting that targeting perennial plantings to slope positions that are most vulnerable to degradation may provide the greatest benefit-cost returns. Another important consideration is that hydrologic flows generally are not distributed uniformly along buffer strip edges ${ }^{64,74}$, and soil water content may also vary with topographic position $^{75}$. Thus, strategically locating perennial vegetation to maximize flow interception can optimize hydrologic regulation and water purification benefits ${ }^{76}$. Nonetheless, placement of buffer strips on the landscape under current practices is often dictated by economic factors ${ }^{77}$, and more work is needed to incorporate approaches for identifying landscape positions for maximizing ES gains into policy and management decisions.

Few studies have assessed the interactive effects of both amount and location of perennial cover on the hydrologic functioning at the watershed scale. One study in central Iowa assessed the effects of varying amounts $(10 \%$ or $20 \%$ of total watershed area) and locations $(20 \%$ all at the bottom or $20 \%$ distributed in contour strips) of native perennial prairie vegetation on sediment and nutrient loss from experimental watersheds ${ }^{78}$. During an extreme rainfall year (2010), watersheds having $100 \%$ annual crops had up to 35 -fold greater sediment loss $(6412 \mathrm{~kg}$ $\mathrm{ha}^{-1}$ ) compared with watersheds having perennial strips $\left(180-314 \mathrm{kgha}^{-1}\right)^{61}$. In a relatively dry year (2009), the differences among treatments were also substantial: 4114 $\mathrm{kg} \mathrm{ha}^{-1}$ sediment lost from watersheds having $100 \%$ crops compared with $129-173 \mathrm{~kg} \mathrm{ha}^{-1}$ from watersheds with perennial strips. Similar results were observed for N: during a wet year (2008) 100\% cropped watersheds had 8 -fold greater $\mathrm{N}$ export $\left(83 \mathrm{~kg} \mathrm{ha}^{-1}\right)$ relative to watersheds with perennial strips $\left(8.1-12.3 \mathrm{~kg} \mathrm{ha}^{-1}\right)$; the difference was 6-fold during a dry year (2009). Patterns observed for P losses were even more pronounced, with $100 \%$ cropped 
watersheds having 11-fold and 16-fold greater P export in 2008 and 2009, respectively, compared with watersheds containing perennial strips. Annual total runoff was 1.6 times greater for watersheds with $100 \%$ crops compared with watersheds with the perennial strips ${ }^{55,56}$. Across all measured variables and years, watersheds with $10 \%$ perennial cover at the bottom unexpectedly performed slightly better than watersheds with $20 \%$ perennial cover distributed as contour strips, and the reason for this is believed to be due to a larger area in perennial cover at the footslope position for the watersheds with $10 \%$ perennial cover at the bottom. The $10 \%$ perennial cover at the bottom treatment had the greatest perennial cover at the footslope position rather than intermixed within the watershed so likely provided the greatest protection in reducing sediment and nutrient loss. However, over time the contour strips distributed within the watershed may provide a naturally terracing effect, which could improve the performance of this treatment. Overall, the findings from this study highlight the potential short-term (2-4 yr) benefits provided by strategically integrating small amounts (as little as $10 \%$ of the entire watershed) of perennial strips within annual cropping systems. More long-term monitoring is needed to understand the longterm functioning of these strips once they become well established.

Although we are unaware of other watershed scale field studies addressing interactions between both amount and location of perennial cover, several other approaches have been used to identify landscape locations for targeting perennial cover to maximize benefits. Geza et al. ${ }^{78}$ used the Soil and Water Assessment Tool (SWAT) to evaluate environmental and economic trade-offs between placing grass filter strips along field drains or targeting their placement to environmentally sensitive areas. While the authors found that placement of the filter strips along field drains was more cost effective, they concluded that the targeted approach would be more environmentally beneficial due to the greater potential for enhancing soil conservation. Terrain analysis has been used to identify sites with large wetness indices ${ }^{74}$, and soil survey and topographic and streamflow data have been combined to develop a system for prioritizing locations for maximizing sediment trapping and surface runoff and/or shallow groundwater flow interception ${ }^{76}$. Geographic information systems and multiple criteria ranking procedures have been used to identify the intersection of hydrologically sensitive and pollutant source areas to develop decision-making processes for effective buffer placement $^{79}$. While these studies have generated similar conclusions - that targeting perennial cover to key areas in agricultural landscapes maximizes environmental benefits-supporting empirical data are lacking for a range of climatic and edaphic conditions.

The selection of particular species or functional groups (e.g., trees versus grasses) can also affect the hydrologic functioning of perennial vegetation, but information is relatively scarce. Studies comparing the hydrologic functions of different species of herbaceous perennials suggest that species may vary substantially in their ability to reduce overland flow ${ }^{80}$ and herbicide leaching ${ }^{81,82}$, and to increase sediment trapping efficiency ${ }^{60,83,84}$ and water uptake $^{85}$. The effectiveness of grass buffers versus mixed grass-tree buffers appears to vary, with some studies suggesting a similar capacity to remove $\mathrm{N}$ and $\mathrm{P}^{9,86}$, while others report greater $\mathrm{N}$ and $\mathrm{P}$ removal ${ }^{51,63}$ and greater infiltration rates ${ }^{57,87}$ under mixed tree-grass riparian buffers compared with grass-only buffers. A paired watershed study found that after 9 years, grass buffer strips significantly decreased runoff by $8.4 \%$, yet there was no significant effect of agroforestry buffer strips, relative to the control ${ }^{88}$. One reason for these contrasting results may be due to the different ages of the tree-based buffers as trees require more time to fully establish before they exhibit positive effects on hydrologic functions ${ }^{89}$. Further, research is lacking on the potential competitive interactions between trees and adjacent crops in temperate agroforestry systems, as water, nutrient and light resources available for crop growth may become more limiting ${ }^{90}$. Overall, improved understanding is needed of how differences in functional type and species composition of perennial vegetation affect hydrologic performance to better select the most suitable mixtures for achieving specific perennialization objectives.

In other climatic regions worldwide, the presence of perennial vegetation in agricultural landscapes can enhance hydrologic services, but impacts vary widely depending on site-specific agroecosystem-climate interactions. For example, in the humid tropics, many traditional agroecosystems comprise combinations of different perennial and annual plants with high structural and compositional complexity, and are often designed to both meet local subsistence needs while simultaneously producing a few specialty high-value market crops ${ }^{91}$. Two classical market-oriented production systems, shade coffee and cacao plantations, which target the production of perennial crops while maintaining relatively high native species diversity, have been shown to maintain similar hydrologic services compared with the native forests ${ }^{92-94}$. Hanson et al. $^{93}$ showed that following conversion of primary forests to grassland, soils had lower saturated hydraulic conductivity and more frequent overland flow compared with soils under traditional shade-grown coffee plantations, while the latter maintained high infiltration capacities and readily conducted water vertically, similar to conditions under primary forest. However, as a result of increasing market pressures and land-use intensification, many shade-grown agroforestry systems are being converted to less diverse and more structurally homogeneous sun-grown plantations ${ }^{95,96}$ or, in some cases, to annual or short duration crops such as sugarcane ${ }^{97,98}$ or oil palm ${ }^{99}$. These transitions from diverse perennial to simplified monocultural systems are often accompanied by negative consequences for hydrologic services ${ }^{100}$. Notably, this 
example underscores the interlinked nature of biodiversity and perenniality: shade-grown coffee systems are typically managed for multiple products in addition to coffee, many for local consumption (e.g., fruits, herbs and medicinals), whereas a transition to sun-coffee generally involves more intensive management of a single product - coffee. Although difficult to disentangle, especially given the lack of controlled studies, it is likely that many of the ES that are enhanced by perennial systems are inextricably linked with the concomitant increase in biodiversity.

In contrast to humid climatic regions, in arid environments the extraction of too much water by perennials can be problematic for water supply, as water use by forests and shrublands is almost always greater than by croplands or grasslands ${ }^{101}$ and planting trees typically reduces annual water yield ${ }^{102}$. In China, where large-scale revegetation initiatives in arid regions have resulted in the planting of millions of hectares of trees ${ }^{103}$, a recent study found that the total water loss due to transpiration from a poplar plantation was $100 \%$ greater than that of adjacent shrubland ${ }^{104}$. Controversy over tree planting and water supply is especially acute concerning exotic species, with much of the debate focusing on fast-growing eucalyptus and pine species ${ }^{105}$. Crucial to determining the overall cost-benefit relationship of planting trees in drylands will be quantifying the net trade-offs between increased transpiration, on the one hand, and improved infiltration and water storage capacity and reduced runoff on the other ${ }^{106}$. Notably, trees in semi-arid regions may provide many ES that outweigh their increased water use, including fuelwood, timber poles, nutritional products and windbreaks ${ }^{107}$, improving soil properties such as porosity ${ }^{108}$, infiltration ${ }^{109,110}$, water storage capacity $^{111}$, and nutrient cycling and soil fertility ${ }^{112}$. Trees may also increase water content in drylands by ameliorating microclimate and reducing soil evaporation $^{113,114}$, or by hydraulic lift or redistribution ${ }^{115-117}$.

In semi-arid areas of Africa, the positive effects of trees in cropping systems are exemplified by farmers' use of Faidherbia (Acacia) albida, a leguminous tree with a reverse phenological pattern relative to most other trees (e.g., leaves drop in the wet season and flush in the dry season), which may reduce competition for resources with crops during the growing season. Crop yields in grain fields with interplanted $F$. albida trees have increased by over $200 \%$, even without additional fertilizer inputs, while these mixed tree-food crop systems also provide multiple benefits such as fuelwood, fodder and enhanced food security during severe drought ${ }^{118,119}$. Similarly, in dry temperate climate regions in China, widespread incorporation of perennial plants into annual row crops is occurring ${ }^{120,121}$, even though most of these lands do not have irrigation. These perennial plantings are being used to reduce sediment and pollutant export ${ }^{122}$, stabilize dunes ${ }^{120}$, conserve soil water and nutrients ${ }^{123}$, enhance $\mathrm{N}$-fixation ${ }^{124}$ and supplement local economic incomes $^{104,125}$. Another positive effect of planting deeprooted perennials in some drylands, such as southern Australia and the African Sahel, is to alleviate problems of salinization of soils and groundwater by lowering water tables ${ }^{43,126}$. Studies have also demonstrated the influence of different types ${ }^{127,128}$ and species ${ }^{129,130}$ of perennial vegetation on enhancing hydrologic functions and reducing sediment and nutrient losses in these regions; however, relatively little work has specifically examined the importance of landscape position.

The impacts of incorporating perennial vegetation within cropping systems on hydrologic services are clearly being documented across different regions and agroecosystems, and these studies are highlighting the importance of considering both the local climate-vegetation interactions and management objectives when selecting suitable perennialzation approaches. Opportunities for significant hydrologic benefits through perennialization may be particularly strong in humid regions where enhanced hydrologic regulation is a priority, while significant ES gains are also being achieved in dryland regions through strategic placement of small amounts of perennial vegetation. More work is required to better understand how varying the spatial location, type and amount of perennial vegetation can differentially influence hydrologic outcomes, especially at the watershed scale, in order to maximize benefits under diverse climatic conditions.

\section{Climate Regulation and Climate Change Mitigation and Adaptation}

Although agroecosystems can provide important climate regulation services through carbon $(\mathrm{C})$ sequestration and storage, they can also increase greenhouse gas emissions as a consequence of biomass burning or accelerated decomposition during forest conversion processes, as well as from chemical and energy inputs ${ }^{131,132}$. Whether an agroecosystem is a net carbon sink or source is directly influenced by management practices and their interaction with local biophysical and climatic conditions ${ }^{133}$. As diverse perennial plant communities typically store more carbon than annual or short-rotation cropping systems ${ }^{10,134}$, perennialization provides an opportunity for mitigating climate change while sustaining agricultural productivity, especially when targeting those species combinations and landscape positions that maximize potential carbon sequestration benefits.

In the Midwestern US, the native tallgrass prairie ecosystem historically stored large amounts of carbon belowground relative to the annual cropping systems they replaced. Conversion of prairie to agriculture resulted in an estimated loss of $24-89 \%$ of the original soil organic $\mathrm{C}$ and total $\mathrm{N}^{135-138}$. Estimated annual accumulation rates of soil organic $\mathrm{C}$ following reestablishment of perennial grasslands on former agricultural lands vary 
greatly, from 19.7 to $78 \mathrm{~g} \mathrm{Cm}^{-2} \mathrm{yr}^{-1}$ in the upper $10 \mathrm{~cm}$ soil horizon ${ }^{136,139-142}$, with average reported rates around $30 \mathrm{~g} \mathrm{Cm}^{-2} \mathrm{yr}^{-2} 143,144$. However, rebuilding soil organic pools to pre-agriculture levels will require time. For the Great Plains region, McLauchlan ${ }^{142}$ estimated that reestablishment of perennial grasslands on former agricultural lands could rebuild soil organic $\mathrm{C}$ pools to levels equivalent to unplowed native prairie within 55-75 years, while Matamala et al. ${ }^{145}$ estimated that within a century restored tallgrass prairie vegetation in Illinois would reach $50 \%$ of its soil C storage potential. Differences in $\mathrm{C}$ accrual rates across sites and soil depths due to variation in root distribution, rhizosphere activity ${ }^{146,147}$ and vertical retranslocation of soil $\mathrm{C}^{47,146}$ may account for some of this variability.

Notably, C storage benefits are quickly lost when perennial vegetation reverts to annual crops, leading to rapid releases of $\mathrm{CO}_{2}$ and other greenhouse gases to the atmosphere ${ }^{140,148}$. Gelfand et al. ${ }^{149}$ examined the greenhouse gas consequences of converting land under the Conservation Reserve Program (CRP) to continuous corn, corn-soybean or perennial grass for biofuel production. They found that projected $\mathrm{C}$ debt repayment periods under no-till management ranged from 29 to 40 years for corn-soybean and continuous corn, respectively, whereas the use of existing CRP grasslands for cellulosic feedstock production would avoid $\mathrm{C}$ debt entirely and provide modest climate change mitigation immediately.

Landscape position can also influence the rate of $\mathrm{C}$ sequestration and storage potential of perennial vegetation. Some studies suggest that $\mathrm{C}$ sequestration potential may be maximized by placing perennial cover in topographical positions with higher moisture availability, such as footslopes and riparian areas ${ }^{135,150}$. On the other hand, because cultivation of sensitive areas such as shoulder and backslope positions may accelerate erosion of soil organic matter ${ }^{151,152}$, targeting topographical positions that are vulnerable to erosion can promote $\mathrm{C}$ retention in the soil. More work is needed to refine understanding of the site-specific features that influence the relationship between topographic position and $\mathrm{C}$ sequestration.

Carbon sequestration potential in soils and plant biomass may also vary depending on both species identity $^{153}$ and functional composition ${ }^{154}$ of the vegetation. In general, trees and shrubs sequester and store greater amounts of $\mathrm{C}$ compared with herbaceous plants due to their larger total above- and below-ground biomass ${ }^{155}$. In the Midwestern US, riparian buffer systems consisting of mixtures of native herbaceous and woody species sequestered significantly greater amounts of C relative to crop fields or cool-season grass buffers ${ }^{54}$. Nevertheless, grassland vegetation can be highly effective at accumulating $\mathrm{C}$ by depositing large amounts of organic matter deeper in the soil horizon where it is protected from decomposition ${ }^{145,156}$. Conversely, woody plants typically deposit a large fraction of total organic matter inputs on the ground surface, where decomposition occurs more rapidly ${ }^{143}$. Knowledge of how different species and functional groups affect rates of $\mathrm{C}$ sequestration, patterns of partitioning of $\mathrm{C}$ between above- and belowground biomass, and soil organic $\mathrm{C}$ accrual and depletion rates is important to take into account when using perennial vegetation as part of climate change mitigation strategies ${ }^{157}$.

Not only do perennials store additional $\mathrm{C}$ relative to annual or simplified cropping systems, perennial plant communities may also enhance agroecosystem resilience and stability to environmental fluctuations, especially when they include high levels of biodiversity ${ }^{22-24,158}$. In the Midwestern USA, conservation agriculture practices are increasingly promoting the use of diverse mixtures of native tallgrass prairie species rather than plantings of a single native or introduced species typically used in the past (e.g., Bromus inermis, brome; Bouteloua cuttipendula, side oats; and Panicum virgatum, switchgrass).

Research suggests that grass and forb species typical to the native tallgrass prairie possess a variety of ecophysiological traits and adaptive strategies that enhance resilience and resistance to climatic extremes, such as high water use efficiency ${ }^{159-161}$, the capacity to senesce and resprout ${ }^{162,163}$, deep roots ${ }^{164,165}$ and high ecological plasticity $^{166,167}$. In addition, greater vertical and horizontal heterogeneity in more diverse plant communities allows for niche partitioning and complementary use of resources ${ }^{168}$, which on the landscape scale can help buffer ecosystems against extreme climate fluctuations ${ }^{169}$. In contrast, annual crops in temperate humid climates are particularly vulnerable to extreme weather conditions, due to a combination of shallow rooting, a relatively short (3-4 months) growth period, high water demand, and high sensitivity to drought and heat stress ${ }^{170-174}$. Perennial plant communities with high species diversity may also have a greater probability of containing species with traits adapted to environmental changes, thus conferring greater 'insurance' relative to plant communities with low species diversity or monocultures ${ }^{175,176}$. Some experimental support for enhanced resilience in diverse perennial plant communities in the context of climate change is emerging ${ }^{177-180}$, especially in terms of greater temporal stability $^{24}$. Nonetheless, the relationship between biodiversity and the sustainability of ES is complex ${ }^{27,181}$, and more work is needed to better design integrated annualperennial landscapes capable of adapting to future climate change while sustaining diverse ES.

In the humid tropics, conversion of forests and traditional agroforestry systems to more intensive agricultural systems has contributed substantially to global greenhouse gas emissions and changes in C stocks ${ }^{182,183}$. In Central America and Mexico, agroforestry systems that maintain a significant tree component, such as shade coffee and cacao plantations, home gardens and tree farms, are particularly effective at sequestering and 
storing $\mathrm{C}$, while providing diverse agricultural products $^{184,185}$. Kirby and Potvin ${ }^{186}$ found that while native forests in Panama managed with selective logging stored more than twice as much $\mathrm{C}$ than forests managed under traditional agroforestry practices, agroforests stored three times more $\mathrm{C}$ than pasture. Expanding agroforests into pasture could provide additional biodiversity and livelihood benefits that the most common reforestation system in the region-monoculture teak plantations-does not provide. A meta-analysis examining the potential for soil organic $\mathrm{C}$ accumulation through afforestation found that planting trees on croplands resulted in more pronounced increases in soil organic $\mathrm{C}$ stocks relative to pastures or grasslands, and that broadleaved tree species had a greater capacity to accumulate soil organic $\mathrm{C}$ than coniferous species $^{187}$.

In dry climatic regions where plant growth is relatively slow and total plant biomass is low, the potential for sequestering and storing $\mathrm{C}$ per unit land area is generally less than in moist climatic regions. However, the total area of degraded drylands that could potentially be restored to perennial vegetation cover is so large that it constitutes a significant potential C sink ${ }^{188}$. Studies in dryland regions of Africa have shown that the amount of soil organic matter below tree canopies is significantly greater compared with open areas due to high inputs of leaf litter and higher root mass ${ }^{189-191}$. In the case of evergreen agricultural systems in semi-arid Africa (discussed previously), incorporating Faidherbia albida trees has been shown to accumulate between $2-4 \mathrm{Mgha}^{-1} \mathrm{yr}^{-1}$ of aboveand below-ground $\mathrm{C}$, which represents a 10 -fold increase over conventional conservation farming systems ${ }^{192-194}$. Targeting of woody perennials in dryland regions for enhanced $\mathrm{C}$ storage should focus on the preservation or introduction of widely dispersed trees within agroecosystems in order to maximize total ES benefits, while maintaining a favorable balance between carbon-water trade-offs.

In semi-arid regions of Africa, the traditional agroforestry parklands are also used by local farmers to adapt and reduce vulnerability to climatic fluctuations and other extreme weather conditions. These parklands typically comprise several species and genera that constitute important sources of medicine, fruits, oils, leaves, nuts and spices that are main components of the local diet ${ }^{115,195-197}$, while also providing fuelwood, feed and an additional income source ${ }^{91}$. Similarly, shade coffee agroforestry systems in the humid tropics have been shown to provide better protection for crop plants from extremes in microclimate and soil moisture relative to low-shade (10-30\%) systems, thus representing an important adaptive strategy for farmers to future climatic extremes ${ }^{198}$. As woody trees and shrubs are often better able to survive extreme weather events such as droughts or floods, they are particularly important for meeting the nutritional and health needs of local people during times of food scarcity.
Although the potential for $\mathrm{C}$ sequestration in agricultural soils worldwide has been estimated to be relatively modest, representing approximately $3-6 \%$ of fossil fuel $\mathrm{C}$ emissions, practices that enhance $\mathrm{C}$ storage within agricultural landscapes are considered an important component of climate change mitigation strategies ${ }^{199}$. Globally, a meta-analysis by Ogle et al. ${ }^{200}$ found that soil organic $\mathrm{C}$ was most sensitive to management impacts in tropical moist regions, followed by tropical dry, temperate moist and, lastly, temperate dry regions. Further, the tropics lose nearly two times as much $\mathrm{C}$ and produce less than one-half the annual crop yield compared with temperate regions ${ }^{201}$. This situation underscores the importance of avoiding clearing more tropical forests for agriculture while balancing agricultural intensification with targeted opportunities for $\mathrm{C}$ sequestration through perennialization of existing agricultural lands ${ }^{182}$. Another promising approach to promoting greater $\mathrm{C}$ sequestration on agricultural lands in both temperate and tropical regions is the use of perennial plants as biofeedstock for cellulosic ethanol production (potentially reducing the use of fossil fuels) combined with application of the charcoal by-product - the biochar - to agricultural soils to increase $\mathrm{C}$ storage over long time periods, given that biochar is highly recalcitrant to degradation (see the 'Provisioning Services' section for a more detailed discussion) $)^{202,203}$.

\section{Biotic Regulation}

Perennialization can increase landscape complexity and resource heterogeneity, thereby promoting habitats for diverse communities of beneficial organisms that help control pests and pathogens, and provide pollination services in adjacent crop fields ${ }^{204}$. Perennials also contribute to food web services by providing habitat for organisms that are a food source for auxiliary biota in the productive or semi-natural sub-systems, and for biota that feed on crop pests ${ }^{205}$.

As perennial vegetation is generally subject to lower levels of disturbance and is more stable over time than are ephemeral annual crop systems (with some exceptions, such as severe over-grazing and hay and grass silage production systems subjected to frequent harvests), various forms of perennial cover can provide critical elements of 'conservation biological control' strategies that seek to retain and facilitate populations of predators and parasitoids that attack arthropod pests in adjacent cropland ${ }^{206-208}$. Both within-field and around-field perennial vegetation can maintain and increase the impacts of natural enemies of crop pests through the provision of alternative prey species, pollen and nectar used as protein and energy sources, and habitat for over-wintering and reproduction ${ }^{11,209-212}$. Within-field diversification with perennial plants can be set up directly by individual farmers, whereas aroundfield diversification with perennials can reflect the 
cumulative impacts of multiple landowners and land managers on landscape structure.

A number of studies indicate that increasing the proportion of landscapes occupied by woodlots, hedgerows, old-field fallows and pastures can enhance biological control of crop pests in fields embedded within those forms of perennial vegetation ${ }^{213,214}$. Tscharntke et al. ${ }^{215}$ reported that parasitism of rape pollen beetles (Meligethes aeneus F.) was greater in German landscapes in which non-crop vegetation occupied $>20 \%$ of total land area compared with landscapes in which non-crop vegetation occupied $<20 \%$ of the land area. In the less diverse landscapes, parasitism of rape pollen beetles was greater at the edges of fields than in the centers; in contrast, in the more vegetatively diverse landscapes, parasitism rates did not differ between field edges and centers. Scale issues were addressed in a study conducted by Gardiner et al. ${ }^{216}$ at sites within four states in the north central US. Densities of predatory coccinellid beetles and rates of biological control of soybean aphid (Aphid glycines) increased as the proportion of landscapes occupied by forest and grassland rose, and the proportion occupied by corn and soybean dropped, with diversity and composition evaluated at a scale of $1.5 \mathrm{~km}$ around focal fields explaining the greatest proportion of variation in coccinellid densities and biological control rates. Thus, for certain host-specific crop pests and their natural enemies, there is likely to be a need for coordinated management activities in establishing and maintaining perennial vegetation at the landscape scale.

Similarly, perennial vegetation can provide a higher abundance and greater diversity of refuges for pollinator populations that are essential for many fruit and vegetable crops. In agriculture, especially among pollen-limited crops, promoting pollination services is an important means of increasing productivity. In a review of pollination services for the leading food crops in 200 countries, Klein et al. ${ }^{217}$ found that of a total of 107 crops traded on the world market that are directly consumed by humans (but excluding crops that are solely passively selfpollinated, wind-pollinated or parthenocarpic), $40 \%$ of these crops are highly to moderately dependent on animal pollinators. Significant declines in different pollinator species have been documented in the Midwestern US, raising several ecological and economic concerns ${ }^{218-220}$. Grixti et al. ${ }^{218}$ noted that half of the bumblebee species found historically in Illinois have been locally extirpated or have suffered declines, supporting observations of broader declines in North America. Major declines in the bumblebee fauna coincided with large-scale agricultural intensification. Bee richness was positively related to plant richness and abundance of potential nesting resources, and bee community composition was significantly related to plant richness, soil characteristics potentially related to nesting suitability, and canopy cover ${ }^{219}$. Conservation of agriculturally important pollinators may be promoted by applying wildlife-friendly approaches to agriculture, such as increasing agricultural land set-asides and hedgerows $^{220}$.

In humid temperate regions, perennial cover crops growing beneath 'main' crops have been shown to contribute to biological control, but they can also reduce crop yields through competition for water and nutrients, making their use problematic in many situations ${ }^{221-224}$. An alternative form of within-field diversification involves the use of narrow strips of perennial vegetation that provide habitat for predators and parasitoids of pests in closely adjacent cropped areas. This approach has been studied in wheat fields where perennial grasses function as 'beetle banks,' conserving coleopteran predators that forage on cereal aphids ${ }^{225,226}$, and in vineyards where strips of flowering plants provide nectar and pollen sources and a corridor from riparian areas for predators attacking thrips and leafhoppers ${ }^{227}$. Strips of alfalfa (Medicago sativa) have been shown to conserve predatory beetles, bugs, lacewings and spiders, and increase their densities in adjacent strips of cotton, thereby exerting greater control of mirid and lepidopteran pests ${ }^{228}$. Strips of perennial grasses, legumes and other forbs left unsprayed with pesticides formed refuges for predatory ground beetles, permitting rapid recolonization of chemically disturbed corn ${ }^{229}$.

Compared with arthropod pests and their natural enemies, the effects of perennial vegetation on crop diseases have received much less attention from the scientific community. In artificially constructed assemblages of perennial prairie species, increases in plant species diversity reduced the severity of diseases caused by wind- and rain-dispersed pathogens on four target plant species (Septoria liatridis on Liatris aspera, Uromyces lespedezae-procumbentis on Lespedeza capitata, Ersiphe cichoracearum on Monarda fistulosa, and Colletotrichum spp. on Schizachyrium scoparium) $)^{230}$, suggesting that diverse mixtures of perennial species interplanted with crops might offer protection against certain pathogens. Such protection could occur as the result of non-crop vegetation acting as a barrier against propagule dispersal, hosting antagonistic and competitive microbes, altering microclimate conditions or inducing resistance within crops $^{231}$. Perennial grain crops may also be bred for high levels of disease resistance. Hayes et al. ${ }^{232}$ noted that wheatgrass species (Thinopyrum and Agropyron spp.) conveyed resistance to many diseases when crossed with wheat to produce perennial hybrids.

Cox et al. ${ }^{233}$ noted that typical cultural practices for reducing soil- and residue-borne pathogens, such as annual crop rotations, delayed planting dates and tillage, are not feasible in perennial crop systems, and that as a consequence, pathogens that survive in soil, crop residues, live shoots and roots may become an increasing threat to perennial crops and adjacent areas of susceptible annual crops over time. To impede the build-up of pathogen populations, Cox et al. $^{233}$ suggested three approaches: planting mixtures of perennial crop cultivars 
or species that vary in disease resistance to particular species and strains of pathogens; using grazing to remove plant residues; and burning plant residues, a natural phenomenon in perennial grass systems that can decrease the incidence and severity of a number of diseases. These methods remain to be field-tested in perennial crop and mixed perennial-annual crop associations, however.

The pest problem is especially important in the humid tropics, where the high rainfall and low seasonality favor two key groups of natural plant enemies - insects and fungi ${ }^{234}$. Consequently, the potential for losing crops to disease is far greater than in more temperate climates. Conserving both the associated fauna within tropical agroforests and surrounding forest fragments with high quality agricultural matrices is critical to maintaining pest regulation services ${ }^{235}$. For example, levels of ant biodiversity exhibit sharp declines with the intensification of coffee and cacao production systems compared with traditional agroforestry systems ${ }^{236}$. High diversity and abundance of ants provide important ES in coffee agroecosystems since ants are an important predator group $^{235,237}$. Another predator studied in the coffee agroforest, birds, helps control coffee berry borers and thus increases coffee yield and farm income, a potentially important conservation incentive for producers ${ }^{238,239}$. Landscape heterogeneity may allow mobile predators to provide pest control broadly, despite localized variation in farming intensities. Similarly, forest remnants provide nearby coffee plantations with a diversity of bees and other pollinators that can increase both the amount and stability of pollination services by reducing dependence on a single introduced pollinator ${ }^{240-242}$, and improve both quantity and quality of coffee yields by reducing the frequency of misshapen seeds ${ }^{242}$.

Recent studies in the dry tropical zone have documented the importance of hedgerows (often planted for soil conservation purposes along sloping land) for enhancing biological pest control by serving as refugia for predators. Girma et al. ${ }^{243}$ found that corn associated with hedgerows comprised of nine different species experienced significantly lower stalk borer (Busseola fusca and Chilo spp.) and aphid (Rhophalosiphum maidis) infestations than pure stands of corn. The study also found, however, that hedgerow effects on pest infestations of crops cannot be generalized but depend on the specific arthropods and their refugia preferences ${ }^{243}$.

Trees have been shown to affect pest infestations in dry tropical agroecosystems by acting as barriers to movement of insects, masking the odors emitted by other components of the system, and sheltering herbivores and natural enemies ${ }^{244}$. In sub-Saharan Africa, where the corn stalk borer, Busseola fusca (Full) (Noctuidae), and the sorghum stem borer, Chilo partellus Swinh (Pyralidae), pose major threats to food production, Khan et al. ${ }^{245,246}$ reported positive effects of trap crop plants (Napier grass, Pennisetum purpureum, and Sudan grass, Sorghum sudanensis) and intercrop plants (molasses grass, Melinis minutiflora, and Desmodium spp.) for controlling stem borer outbreaks through release of attractant and repellent semiochemicals.

Currently, it is difficult to view perennial vegetation as a panacea for crop pest and disease problems, though promising opportunities for improved management strategies clearly exist. The generally positive influence of perennial vegetation on biological control is not necessarily consistent from year to year ${ }^{247}$. Moreover, in some cases perennial vegetation can exacerbate pest problems by serving as an alternate host to crop pests, as is the case for soybean aphid, which resides on buckthorn (Rhamnus spp.) growing in hedgerows and woodlands adjacent to soybean fields in the Midwestern USA ${ }^{248}$. Much more needs to be learned concerning sources of spatial and temporal variability in the effects of perennial vegetation on natural enemies of crop pests and crop disease dynamics, and a much more detailed understanding needs to be developed concerning how individual perennial species affect natural enemies of arthropod pests, crop pathogens and crop yields.

\section{Soil Quality and Nutrient Cycling}

Soil quality is the capacity of a soil to sustain biological productivity, maintain environmental quality, and promote plant and animal health ${ }^{249,250}$. Consequently, soil quality is a required supporting service for agroecosystems and human societies. Over the past several decades, soil scientists have assembled sets of physical, chemical and biological indicators of soil quality ${ }^{249}$. Physical indicators include rates of water flow into and through soil; soil structural characteristics, such as porosity, bulk density and aggregate size distribution; and measures of stability, such as aggregate stability in water and erosion rate. Chemical indicators include quantities and qualities of soil organic $\mathrm{C}$ and $\mathrm{N}$, nutrient availability to plants and soil reaction $(\mathrm{pH})$. Biological indicators include the mass of organisms in soil and measures of their physiological activity, including rates of respiration and enzymatic reactions.

Regular additions of organic matter, especially root materials, play a critical role in the maintenance of soil quality ${ }^{251,252}$. In general, in humid, temperate environments, woody and herbaceous perennial plants add more root material and organic matter to soil than do annual crops $^{53,54}$ and consequently they are more effective at maintaining soil quality. As noted in the previous sections on hydrologic regulation and climate regulation, rainfall infiltration, hydraulic conductivity and soil C storage are greater for soil occupied by trees and herbaceous perennials than annual row crops.

Adding perennial crops to rotation sequences dominated by annual crops can have beneficial effects on soil quality and function. Residues of alfalfa, red clover and 
other perennial forage legumes can release enough $\mathrm{N}$ to satisfy much or all of the nitrogen demand of subsequent cereal crops, such as corn nitrogen ${ }^{253,254}$. Russell et al. ${ }^{255}$ compared cropping systems based on annual crops (continuous corn or a corn-soybean rotation) with systems that contained alfalfa as well as corn and soybean and found that systems containing alfalfa had greater available $\mathrm{N}$, higher rates of potential net $\mathrm{N}$ mineralization, and more microbial biomass $\mathrm{C}$. Soil total $\mathrm{N}$ and organic $\mathrm{C}$ concentrations were also higher in systems containing alfalfa. Thus, cropping systems that contain perennial legumes in sequence with annual crops can have lower requirements for fertilizer and higher rates of soil C storage ${ }^{256,257}$.

More efficient $\mathrm{N}$ use by perennials can potentially reduce the environmental impacts associated with nutrient losses. Nitrogen losses to drainage water are greater for corn and soybean than for perennial grasses and herbaceous legumes such as alfalfa ${ }^{258}$. Moreover, trees can have even higher $\mathrm{N}$ and $\mathrm{P}$ removal efficiency than perennial grasses ${ }^{54,67}$. In Iowa, $\mathrm{N}$ immobilization rates in poplar stands and switchgrass sites averaged 37 and $16 \mathrm{~kg} \mathrm{Nha}^{-1} \mathrm{yr}^{-1}$, respectively ${ }^{54}$.

For humid tropical regions, which typically have soils of low fertility ${ }^{259}$, it is especially important to develop land-use systems that promote efficient nutrient cycling $^{260}$. Land-use systems based on tree crops (e.g., multistrata agroforestry systems) have clear advantages over annual cropping systems for the maintenance of soil fertility because they provide permanent soil cover and root systems ${ }^{260}$. For example, when shade coffee agroforestry systems are converted to more intensive sun-grown systems by removing the shade trees, $\mathrm{N}$ fertilizers are usually applied at high rates to maintain productivity. Research assessing the consequences of these changes for nitrate leaching and water quality has yielded contrasting results ${ }^{261-263}$. Babbar and $\mathrm{Zak}^{261}$ reported lower $\mathrm{N}$ leaching rates from shaded than from unshaded coffee cultivation in Costa Rica ( 9 versus $24 \mathrm{kgha}^{-1} \mathrm{yr}^{-1}$, respectively), though plantations differed in the density and pruning regime of the coffee plants, making the data difficult to interpret. Harmand et al. ${ }^{263}$ found that drainage was slightly reduced in a shaded compared with an unshaded coffee plantation, but $\mathrm{N}$ losses in surface runoff were low in both cases. In general, shade coffee systems appear to have greater potential to enhance other soil fertility properties such as nutrient and organic inputs from litterfall ${ }^{262,264}$ and earthworm density ${ }^{265}$ than their unshaded counterparts.

In arid agricultural regions of East Africa, retaining savanna trees as part of annual cropping systems can enhance soil fertility ${ }^{266}$ and, in turn, understory crop production $^{267,268}$. Perennialization can also help mitigate or even reverse processes of soil loss and desertification, common in many drylands, by reducing the movement of sand, retaining soil organic matter and promoting establishment of new vegetation. For example, in the
Loess Plateau region of China, Qiao et al. ${ }^{120}$ demonstrated that mixed tree plantations interspersed within cropland can, over time, help stabilize and facilitate the restoration of native vegetation. Yuan et al. ${ }^{269}$ studied the effects of mixing wheat with three perennials (Stipa bungeana, Lespedeza davurica and Artemesia capillaries) in the same region, and found that the perennials significantly increased the total crop production, especially root growth.

Overall, the influence of perennials on soil fertility is synergistically coupled with their impact on hydrologic and $\mathrm{C}$ sequestration services, and thus, multiple ES can be obtained through perennialization processes in cropland. However, as with hydrological and $\mathrm{C}$ sequestration services, more work is needed to improve understanding of how different species mixtures, amounts and landscape positions influence soil quality properties, in both temperate and humid agroecosystems.

\section{Provisioning Services}

Food, fiber and fuel production to meet subsistence or market needs is the overwhelmingly dominant goal of agriculture. Crops in individual fields are dependent on services provided by nearby ecosystems, whether native or managed, and nearby ecosystems are often influenced by their agricultural neighbors ${ }^{7}$. As discussed above, perennialization can contribute toward maximizing ES benefits from agricultural landscapes. Below, we review opportunities for accomplishing this goal, with an emphasis on the additional provisioning services that perennial plants also provide.

\section{Forage crops}

Following the large-scale introduction in the 1940s and 1950s of relatively inexpensive synthetic fertilizers, farming systems in humid temperate regions have become increasingly specialized, with fewer crops grown within rotation sequences and fewer livestock enterprises integrated with crop enterprises ${ }^{270,271}$. As a consequence, in regions such as the US Corn Belt, annual grain crops such as corn and soybean have greatly displaced perennial forages, and cattle are often produced in large feedlots, from which manure application to a sufficiently large land base can be problematic. Nonetheless, recent increases in fertilizer and feed costs have led to renewed interest in integrated crop-livestock systems that include perennial species used for pasture and hay, and which exploit the recycling of $\mathrm{C}$ and nutrients via manure application to croplands ${ }^{272}$. Expanding crop sequences based only on annual species to include perennial forages, and returning manure to croplands, can have numerous benefits. As summarized by Russelle et al. ${ }^{273}$, these include reduced nitrate leaching to groundwater, reduced rates of erosion by wind and water, increased soil $\mathrm{C}$ content and soil water 
holding capacity, greater biological $\mathrm{N}$ fixation and improved nutrient supply, reduced incidence of pests, enhanced grain yield potential, lower fossil energy demands, reduced production costs and improved profitability. Despite these advantages, major disincentives to crop-livestock integration can exist within government farm policies. In the US, for example, disincentives have included subsidies for annual crops, but not perennial forages, and a lack of accounting for costs of the environmental impacts of farming systems. In contrast, Sulc and Tracy ${ }^{271}$ noted, '... there is significant research investment in and adoption of integrated crop-livestock systems in countries where government price supports for agriculture are limited or nonexistent (e.g., Brazil, New Zealand).'

\section{Grain crops}

Although all of the world's current staple grains are annual species, concerns over soil erosion, agrichemical pollution, maintenance of soil organic $\mathrm{C}$ stocks and energy costs of tillage have propelled interest among some plant breeders in the development of perennial grain crops $^{149,274}$. Cox et al. $^{274}$ reviewed parental germplasm and methodologies for breeding at least 20 species of perennial grains. Possible approaches to developing perennial grain crops include using related perennial species to add genes into annual crops such as wheat, and domesticating existing perennial species, such as intermediate wheatgrass (Thinopyrum intermedium), Maximilian sunflower (Helianthus maximiliani) and Illinois bundleflower (Desmanthus illinoensis), through selection for higher seed production and desirable agronomic and quality factors. Important biological and technical challenges exist for both approaches, but these might be surmountable in much less time than the millennia that were required to domesticate wheat, maize, rice and other grains ${ }^{71}$.

Perennial grain crops may have a lower yield potential than annuals due to trade-offs between seed productivity and longevity: resources that might be allocated to seeds may instead have to be allocated to non harvested perennating structures to maintain survival from year to year $^{275}$. Cox et al. $^{275}$ argued, however, that perennial grain crops do have the potential to produce high and acceptable seed yields because (1) compared with annual crops, perennials tend to have longer growing seasons, greater canopy cover duration, and deeper rooting depths, allowing them to intercept, retain and utilize more precipitation, nutrients and light; and (2) perennials generally produce more above-ground biomass than do annuals and a greater proportion of that biomass might be reallocated to grain production through breeding. DeHaan et al. ${ }^{276}$ and Van Tassel et al. ${ }^{277}$ noted that low yields from perennial grain crops to date reflect a lack of attention from plant breeders and they predicted that artificial selection in a properly managed agricultural environment could increase seed yield while maintaining perenniality. In one of the few studies reporting the seed yields of perennial grain crops subjected to artificial selection, Scheinost et al. ${ }^{278}$ observed that promising lines of perennial wheat produced $1.7-5.8 \mathrm{Mgha}^{-1}$, as compared with $9.0 \mathrm{Mgha}^{-1}$ from an annual wheat cultivar commonly grown in the area. Murphy et al. ${ }^{279}$ reported that amphiploid breeding lines derived from crosses between annual wheat and the perennial wheatgrass species Thinopyrum elongatum produced mean grain yields of $0.6-2.2 \mathrm{Mgha}^{-1}$, depending on location, which were about $44 \%$ of the seed yield of annual wheat grown at the locations. It remains to be learned how much improvement in perennial grain yields can be realized through breeding. Adjustments in soil fertility may be necessary to increase the seed yields of perennial grain species. Loeppky et al. ${ }^{280}$ reported that in northeastern Saskatchewan, seed yields of crested wheatgrass (Agropyron cristatum) and intermediate wheatgrass (A. intermedium) could be increased with the application of $\mathrm{N}$ and $\mathrm{P}$ fertilizers on soils with low levels of available nutrients. Additional research is needed to better assess the economics of perennial grain production systems, since reduced revenues due to lower yields might be offset by reduced input costs for seeds and land preparation.

\section{Biofuel crops}

Growing concerns over the instability of petrochemical prices, heavy dependence on foreign sources of petrochemicals and the environmental impacts of fossil fuel combustion (including greenhouse gas emissions) have led to rapid growth during the past decade in the use of plant materials to produce liquid transportation fuels. In the humid temperate zone, major emphasis has been placed on the use of corn grain to produce ethanol, and soybean and rapeseed to produce biodiesel. The resulting rise in prices of these crops has been viewed favorably by many crop farmers, but has also given rise to pointed critiques on a number of grounds. Partly, but not entirely, because of increased demand from the bioenergy sector for commodity crops, livestock feed costs and food prices for consumers jumped upward in 2006-2007 and may in the future impose financial and nutritional burdens on low-income people in both developed and developing countries $^{281}$. Increased crop prices may also spur conversion of land currently in perennial vegetation to arable cropland, with attendant increases in $\mathrm{N}$ emissions to water supplies ${ }^{279}$ and greenhouse gas emissions to the atmosphere $^{149,282,283}$.

Increasing attention to the development of thermochemical and biochemical technologies for converting lignocellulosic materials into liquid fuels and other industrial chemicals adds new twists to the biofuels story. Unlike the currently dominant biofuel technologies that rely on the use of seeds, lignocellulosic conversion processes utilize plant stems and leaves. Consequently, 
research is being directed to the use of perennial grasses, such as switchgrass (Panicum virgatum) and miscanthus (Miscanthus spp. and interspecific hybrids such as $M . \times$ giganteus $)$, and fast-growing tree species, such as poplar (Populus spp.) and willow (Salix spp.), as dedicated bioenergy feedstock crops ${ }^{284-289}$. Precedence for the use of dedicated perennial crops as biofuel feedstocks has already been set in Brazil, where sugarcane (Saccharum officinarum) is used for ethanol production ${ }^{290}$.

Concerns have been raised over the potential for perennial bioenergy crops to become invasive pests ${ }^{291}$, and protocols should be in place to avert this problem before introductions of non-native species or newly developed genotypes proceed. Tilman et al. ${ }^{24}$ proposed the use of diverse mixtures of native prairie plants as bioenergy feedstocks on degraded, low-fertility land, which minimizes risks of introducing noxious species, but also limits the quantities of biomass that might be produced. Further, while removal of large amounts of annual crop biomass can reduce soil fertility and organic C stocks ${ }^{292,293}$, removal of above-ground portions of perennial plants used as bioenergy feedstocks can still allow for the maintenance of soil fertility and organic carbon, since large quantities of nutrients are translocated below ground before shoot harvest, and the more extensive root systems of perennials can sequester sizeable amounts of carbon ${ }^{283,294-296}$. Residues of biofuel feedstocks can be spread after processing on soil as amendments to return nutrients and $C^{297,298}$.

An important option for the production of perennial biofuel feedstock crops is to use them as one element of multifunctional agricultural landscapes ${ }^{299}$. By placing well-adapted perennial biofuel crops on small, but vulnerable portions, of landscapes, soil, water and wildlife conservation benefits might be gained, while providing farmers an additional opportunity for producing a marketable crop ${ }^{6,300}$. Rotations including perennials and crops, given an appropriate level of management, could be a great opportunity to support the production of biomass and grain while maintaining soil quality over the long term on high-quality agricultural lands. This is especially important in regions with low fertility and where nutrients remain a major constraint, such as in rain-fed farming systems throughout the tropics. Perennials have also been proposed as the major bioenergy plants for the dry temperate zone of China, including short-rotation woody plants and native Achnatherum spp., Agropyron, and other species ${ }^{301}$.

\section{Medicinal products}

Another valuable service of perennial plants integrated within agricultural landscapes in many regions worldwide is to provide medicinal products. In China, regardless of Western advances in medical sciences, people rely heavily on medicines derived from combinations of locally produced plants and animals; the majority of medicinal plants are perennials ${ }^{302,303}$. In Xingjiang Province alone, for example, 2014 plant species have been used in medical practices, among which 558 species are cultivated $^{125}$. In the dry tropics of Africa the situation is similar, with a long and rich history of traditional use of perennial plants as medicines, and new phytochemical research has started to link specific plant properties with targeted effects on human health ${ }^{304,305}$. In the wet tropics, there is a long tradition of producing medicinal plants as integral components of home gardens ${ }^{91}$.

The above discussion calls attention to the wide range of opportunities that exist for contributing a diverse array of food, fiber and fuel products to human societies through perennial plants. In some cases, these agroecosystems may be dominated by perennial plants, such as in the case of large-scale biofuel production or rotational cropping or grazing systems, but in many situations, they will likely involve the targeted placement of relatively small amounts of perennials in strategic locations as part of a matrix of annual crops. An important focus of future research will be to identify which landscape positions - as well as how much and what type of perennial cover-will provide the greatest benefit in terms of both agricultural products and other diverse ES under contrasting climatic conditions, and to meet different production goals by local communities.

\section{Conclusions}

As the global society faces the challenge of meeting increased demand for food, fiber and animal feed to sustain growing populations, while at the same time adapting to a changing climate, agricultural landscapes will likely undergo unprecedented transitions in the near future $^{306}$. Central questions will involve determining the relative value and priority to be given to the many ES provided by agricultural landscapes in addition to food, fiber and feed, and how to best balance these multiple benefits, or in other words, how to harmonize agricultural production and conservation ${ }^{307}$. In this paper, we used the Corn Belt region of the Midwestern USA as a model system for highlighting examples where scientific research on perennialization of agricultural landscapes has documented progress toward achieving this goal. In particular, we showed how a targeted approach identifies landscape locations and the type and amount of perennial cover for maximizing benefit-cost trade-offs for multiple ES important to society, and thereby providing opportunities for designing multifunctional agroecosystems. We also emphasized that because perenniality and biodiversity are often inextricably and positively linked, and most studies on perennialization to date have not considered their independent effects on enhancing ES, more work in needed to disentangle the relative importance of these two variables. Finally, we highlighted differences in both the constraints and 
opportunities for perennializing agricultural landscapes among different climate regions globally, in addition to critical gaps in knowledge where more information is needed. Notably, the evidence to date regarding the potential contributions of perennialization to balancing agricultural production and conservation are primarily based on controlled field studies such as those mentioned in this review; the effectiveness of perennialization approaches at the operational scale with farmer participation remains to be tested in the future.

Although an in-depth discussion of the political and socio-economic environment needed to promote perennialization is beyond the scope of the present paper, it is important to acknowledge that effective policy structures and mechanisms, market opportunities, institutional frameworks and infrastructural arrangements will be critical to establish incentives that favor adoption of perennial-based agricultural practices ${ }^{308,309}$. One of the major current constraints to perennialization is that the most economically profitable decision is frequently to grow only a few crop types, and not to invest in conservation of the varieties that are less favored by existing markets. The problem lies both in the public good nature of conservation, and the fact that currently there are no major markets for off-site ES that depend on on-farm agrobiodiversity ${ }^{310}$. Notwithstanding, there are a growing number of initiatives worldwide that seek to create markets for these services, ranging from those based strictly on government intervention to others that are entirely private ventures ${ }^{31,312}$. In the USA, the Conservation Reserve Program (CRP) provides monetary incentives to farmers to put cropland into various forms of perennial vegetation, with the original intent of reducing soil erosion. However, this mechanism is vulnerable to fluctuations in land and crop values, as seen by the rapid broad-scale conversion of CRP back to crops in recent years in response to the increasing biofuel economy ${ }^{313}$. In the developing world, examples of policies to counter market drivers favoring conversion of traditional, highly diverse perennial-based agroecosystems to more simplified systems include mechanisms such as certification $^{314,315}$, payment for $\mathrm{ES}^{316-318}$ and reducing emissions from deforestation ${ }^{319}$.

Moreover, it will also be important to quantify the economic implications of perennialization that include the less tangible values of the ES and not only the crops. There are several examples suggesting positive relationships between increasing agroecosystem biodiversity and income for different ES, including pollinator abundance $^{222,320}$, pest control $^{219}$, C sequestration $^{319}$ and water quality protection ${ }^{100,321}$. Gallai et al. ${ }^{320}$ estimated that the total economic value of pollination worldwide at $\$ 153$ billion, which represents $9.5 \%$ of the value of the world agricultural production used for human food in 2005. With rare exception, these services are neither prized by markets nor explicitly protected by the law, even though economic studies propose that properly constructed markets would support strong conservation measures ${ }^{2}$. For public policy decisions to take them into account, non market valuation techniques are urgently needed $^{7}$. Economic and social benefits may also be conferred by perennial vegetation through enhanced resilience and stability of agroecosystems, thereby contributing to society's ability to adapt to and cope with climate change en $^{322-324}$

In order for perennialization practices-and the policies and programs that promote them - to be effective in the long term, scientifically sound data quantifying the effects of perennialization on different ES and identifying specific practices - in terms of what, where and how much perennial cover - that produce maximum benefitcost trade-offs, will be critical. Our review of the literature suggests that there is substantial scientific evidence suggesting that increasing the presence of perennial vegetation in cropping systems generally leads to greater ES. However, current knowledge about the relationship between the spatial configuration, amount and type of perennial vegetation, and the specific ES impacts is relatively scarce. Further, long-term, replicated studies at the watershed scale, which are critical to addressing the impacts of perennialization on hydrologic services and their relation to other ES, are particularly lacking. Finally, there is generally more information available from temperate climate regions compared with tropical regions. Future work should focus on advancing scientific understanding to address these gaps in order to provide a baseline for designing approaches that enable targeting the placement of appropriate amounts and types of perennial vegetation in strategic locations on the landscape to minimize economic and production costs while enhancing ES.

Acknowledgements. The authors thank the Leopold Center for Sustainable Agriculture, Iowa State University College of Agriculture and Life Sciences, USDA Forest Service Northern Research Station, Iowa Department of Agriculture and Land Stewardship, USDA North Central Region SARE program, USDA AFRI Managed Ecosystems, and the Great Lakes Bioenergy Research Center (GLBRC), for providing funding to support their research activities related to this paper. We also thank Drake Larsen for his assistance with producing the visualizations included in the two figures.

\section{References}

1 Foley, J.A., DeFries, R., Asner, G.P., Barford, C., Bonan, G., Carpenter, S.R., Chapin, F.S., Coe, M.T., Daily, G.C., Gibbs, H.K., Helkowski, J.H., Holloway, T., Howard, E. A., Kucharik, C.J., Monfreda, C., Patz, J.A., Prentice, I.C., Ramankutty, N., and Snyder, P.K. 2005. Global consequences of land use. Science 309:570-574.

2 MEA. 2005. Millenium Ecosystem Assessment. Ecosystems and Human Well-Being, Synthesis. MEA, Washington, DC.

3 Tilman, D., Cassman, K.G., Matson, P.A., Naylor, R., and Polasky, S. 2002. Agricultural sustainability and intensive production practices. Nature 418:671-677. 
4 Power, A.G. 2010. Ecosystem services and agriculture: tradeoffs and synergies. Philosophical Transactions of the Royal Society B: Biological Sciences 365:2959-2971.

5 Boody, G., Vondracek, B., Andow, D.A., Kinke, M., Westra, J., Zimmerman, J., and Welle, P. 2005. Multifunctional agriculture in the United States. BioScience 55:27-38.

6 Schulte, L.A., Liebman, M., Asbjornsen, H., and Crow, T. R. 2006. Agroecosystem restoration through strategic integration of perennials. Journal of Soil and Water Conservation 61:164A-169A.

7 Swinton, S.M., Lupi, F., Robertson, G.P., and Hamilton, S.K. 2007. Ecosystem services and agriculture: cultivating agricultural ecosystems for diverse benefits. Ecological Economics 64:245-252.

8 Gerla, P.J. 2007. Estimating the effect of cropland to prairie conversion on peak storm run-off. Restoration Ecology 15:720-730.

9 Duchemin, M. and Hogue, R. 2009. Reduction in agricultural non-point source pollution in the first year following establishment of an integrated grass/tree filter strip system in southern Quebec (Canada). Agriculture Ecosystems and Environment 131:85-97.

10 Zan, C.S., Fyles, J.W., Girouard, P., and Samson, R.A. 2001. Carbon sequestration in perennial bioenergy, annual corn and uncultivated systems in southern Quebec. Agriculture Ecosystems and Environment 86:135-144.

11 Fiedler, A.K. and Landis, D.A. 2007. Attractiveness of Michigan native plants to arthropod natural enemies and herbivores. Environmental Entomology 36:751-765.

12 Moonen, A.-C. and Barberi, P. 2008. Functional biodiversity: an agroecosystem approach. Agriculture, Ecosystems and Environment 127:7-21.

13 Fonte, S.J. and Six, J. 2010. Earthworms and litter management contributions to ecosystem services in a tropical agroforestry system. Ecological Applications 20:1061-1073.

14 Milestad, R., Ahnstrom, J., and Bjorklund, J. 2011. Essential multiple functions of farms in rural communities and landscapes. Renewable Agriculture and Food Systems 26:137-148.

15 Deryng, D., Sacks, W.J., Barford, C.C., and Ramankutty, N. 2011. Simulating the effects of climate and agricultural management practices on global crop yield. Global Biogeochemical Cycles 25:GB2006. DOI: 10.1029/2009GB003765.

16 Schlenker, W. and Roberts, M.J. 2009. Nonlinear temperature effects indicate severe damages to US crop yields under climate change. Proceedings of the National Academy of Sciences of the United States of America 106:15594-15598.

17 Challinor, A.J., Wheeler, T.R., Craufurd, P.Q., Ferro, C.A.T., and Stephenson, D.B. 2007. Adaptation of crops to climate change through genotypic responses to mean and extreme temperatures. Agriculture, Ecosystems and Environment 119:190-204.

18 Gregory, P.J. and Ingram, J.S.I. 2000. Global change and food and forest production: future scientific challenges. Agriculture, Ecosystems and Environment 82:3-14.

19 Motha, R.P. and Baier, W. 2005. Impacts of present and future climate change and climate variability on agriculture in the temperate regions: North America. Climatic Change 70:137-164.

20 Smith, P. and Olesen, J.E. 2010. Synergies between the mitigation of, and adaptation to, climate change in agriculture. Journal of Agricultural Science 148:543-552.

21 Tilman, D., Knops, J., Wedin, D., Reich, P., Ritchie, M., and Siemann, E. 1997. The influence of functional diversity and composition on ecosystem processes. Science 277:1300-1302.

22 Lin, B.B. 2011. Resilience in agriculture through crop diversification: adaptive management for environmental change. BioScience 61:183-193.

23 Jackson, L.E., Pascual, U., and Hodgkin, T. 2007. Utilizing and conserving agrobiodiversity in agricultural landscapes. Agriculture Ecosystems and Environment 121:196-210.

24 Tilman, D., Hill, J., and Lehman, C. 2006. Carbonnegative biofuels from low-input high-diversity grassland biomass. Science 314:1598-1600.

25 Solomon, S., Qin, D., Manning, M., Chen, Z., Marquis, M., Averyt, K.B., Tignor, M., and Miller, H.L. (eds). 2007. Contributions of Working Group I to the Fourth Assessment Report of the Intergovernmental Panel on Climate Change. Cambridge University Press, Cambridge, UK.

26 DiFalco, S. and Chavas, J.P. 2008. Rainfall shocks, resilience, and the effects of crop biodiversity on agroecosystem productivity. Land Economics 84:83-96.

27 Lin, B.B., Perfecto, I., and Vandermeer, J. 2008. Synergies between agricultural intensification and climate change could create surprising vulnerabilities for crops. BioScience 58:847-854.

28 Kremen, C., Williams, N.M., Bugg, R.L., Fay, J.P., and Thorp, R.W. 2004. The area requirements of an ecosystem service: crop pollination by native bee communities in California. Ecology Letters 7:1109-1119.

29 Ricketts, T.H., Regetz, J., Steffan-Dewenter, I., Cunningham, S.A., Kremen, C., Bogdanski, A., GemmillHerren, B., Greenleaf, S.S., Klein, A.M., Mayfield, M.M., Morandin, L.A., Ochieng, A., and Viana, B.F. 2008. Landscape effects on crop pollination services: are there general patterns? Ecology Letters 11:499-515.

30 Brussaard, L., Caron, P., Campbell, B., Lipper, L., Mainka, S., Rabbinge, R., Babin, D., and Pulleman, M. 2010. Reconciling biodiversity conservation and food security: scientific challenges for a new agriculture. Current Opinion in Environmental Sustainability 2:34-42.

31 Dale, V.H. and Polasky, S. 2007. Measures of the effects of agricultural practices on ecosystem services. Ecological Economics 64:286-296.

32 Pretty, J. 2008. Agricultural sustainability: concepts, principles and evidence. Philosophical Transactions of the Royal Society B: Biological Sciences 363:447-465.

33 Robertson, G.P. and Swinton, S.M. 2005. Reconciling agricultural productivity and environmental integrity: a grand challenge for agriculture. Frontiers in Ecology and the Environment 3:38-46.

34 Chan, K.M.A., Shaw, M.R., Cameron, D.R., Underwood, E.C., and Daily, G.C. 2006. Conservation planning for ecosystem services. PLoS Biology 4:2138-2152.

35 USDA 2005. Agricultural Statistics Data Base. Department of Agriculture, National Agricultural Statistics Service, United States. 
36 NASS 2004. Census of Agriculture 2002. US Department of Agriculture, Washington, DC.

37 Dahl, T.E. and Allord, G.J. 1996. History of wetlands in the conterminous United States: National Water Summary on Wetland Resources. US Geologic Survey, Washington, DC.

38 Goolsby, D.A. and Battaglin, W.A. 2001. Long-term changes in concentrations and flux of nitrogen in the Mississippi River Basin, USA. Hydrological Processes 15:1209-1226.

39 Jaynes, D.B., Hatfield, J.L., and Meek, D.W. 1999. Water quality in Walnut Creek watershed: herbicides and nitrate in surface waters. Journal of Environmental Quality 28:4559.

40 Aneja, V.P., Blunden, J., Roelle, P.A., Schlesinger, W.H., Knighton, R., Niyogi, D., Gilliam, W., Jennings, G., and Duke, C.S. 2008. Workshop on agricultural air quality: state of the science. Atmospheric Environment 42:31953208.

41 Knox, J.C. 2001. Agricultural influence on landscape sensitivity in the Upper Mississippi River Valley. Catena 42:193-224.

42 Farrar, D. 1981. Perspectives on Iowa's declining flora and fauna - a symposium. Proceedings of the Iowa Academy of Science 88:16.

43 Scanlon, B.R., Jolly, I., Sophocleous, M., and Zhang, L. 2007. Global impacts of conversions from natural to agricultural ecosystems on water resources: quantity versus quality. Water Resources Research 43, W03437.

44 Tilman, D., Fargione, J., Wolff, B., D'Antonio, C., Dobson, A., Howarth, R., Schindler, D., Schlesinger, W.H., Simberloff, D., and Swackhamer, D. 2001. Forecasting agriculturally driven global environmental change. Science 292:281-284.

45 Schilling, K.E. and Libra, R.D. 2003. Increased baseflow in Iowa over the second half of the 20th century. Journal of the American Water Resources Association 39:851-860.

46 Knox, J.C. 1987. Historical valley floor sedimentation in the Upper Mississippi Valley. Annals of the Association of American Geographers 77:224-244.

47 David, M.B., McLsaac, G.F., Darmody, R.G., and Omonode, R.A. 2009. Long-term changes in mollisol organic carbon and nitrogen. Journal of Environmental Quality 38:200-211.

48 Rabalais, N.N., Diaz, R.J., Levin, L.A., Turner, R.E., Gilbert, D., and Zhang, J. 2010. Dynamics and distribution of natural and human-caused hypoxia. Biogeosciences 7:585-619.

49 Anderson, S.H., Udawatta, R.P., Seobi, T., and Garrett, H.E. 2009. Soil water content and infiltration in agroforestry buffer strips. Agroforestry Systems 75:5-16.

50 Brye, K.R., Norman, J.M., Bundy, L.G., and Gower, S.T. 2000. Water-budget evaluation of prairie and maize ecosystems. Soil Science Society of America Journal 64:715-724

51 Seobi, T., Anderson, S.H., Udawatta, R.P., and Gantzer, C.J. 2005. Influence of grass and agroforestry buffer strips on soil hydraulic properties for an Albaqualf. Soil Science Society of America Journal 69:893-901.

52 Yunusa, I.A.M., Mele, P.M., Rab, M.A., Schefe, C.R., and Beverly, C.R. 2002. Priming of soil structural and hydrological properties by native woody species, annual crops, and a permanent pasture. Australian Journal of Soil Research 40:207-219.

53 Liebig, M.A., Johnson, H.A., Hanson, J.D., and Frank, A.B. 2005. Soil carbon under switchgrass stands and cultivated cropland. Biomass and Bioenergy 28:347-354.

54 Tufekcioglu, A., Raich, J.W., Isenhart, T.M., and Schultz, R.C. 2003. Biomass, carbon and nitrogen dynamics of multi-species riparian buffers within an agricultural watershed in Iowa, USA. Agroforestry Systems 57:187-198.

55 Hernandez-Santana, V., Zhou, X., Helmers, M.J., Asbjornsen, H., Kolka, R., and Tomer, M.D. 2012. Native prairie filter strips reduce runiff from hillslopes under annual row-crop systems in Iowa, USA. Journal of Hydrology 477:94-103.

56 Wang, Z. 2008. Soil porosity of different cropping management systems with perennial plants. Journal of Soil and Water Conservation 1:10-11.

57 Schilling, K.E., Jha, M.K., Zhang, Y.K., Gassman, P.W., and Wolter, C.F. 2008. Impact of land use and land cover change on the water balance of a large agricultural watershed: historical effects and future directions. Water Resources Research 44:W00A09.

58 Bharati, L., Lee, K.H., Isenhart, T.M., and Schultz, R.C. 2002. Soil-water infiltration under crops, pasture, and established riparian buffer in Midwestern USA. Agroforestry Systems 56:249-257.

59 Steward, D.R., Yang, X., Lauwo, S.Y., Staggenborg, S.A., Macpherson, G.L., and Welch, S.M. 2011. From precipitation to groundwater baseflow in a native prairie ecosystem: a regional study of the Konza LTER in the Flint Hills of Kansas, USA. Hydrology and Earth System Sciences 15(10):3181-3194.

60 Blanco-Canqui, H., Gantzer, C.J., Anderson, S.H., and Alberts, E.E. 2004. Grass barriers for reduced concentrated flow induced soil and nutrient loss. Soil Science Society of America Journal 68:1963-1972.

61 Helmers, M.J., Zhou, X., Asbjornsen, H., Kolka, R., Tomer, M.D., and Cruse, R.M. 2012. Sediment removal by prairie filter strips in row-cropped ephemeral watersheds. Journal of Environmental Quality 41:1531-1539.

62 Leguedois, S., Ellis, T.W., Hairsine, P.B., and Tongway, D.J. 2008. Sediment trapping by a tree belt: processes and consequences for sediment delivery. Hydrological Processes 22:3523-3534.

63 Lee, K., Isenhart, T.M., and Schultz, R.C. 2003. Sediment and nutrient removal in an established multispecies riparian buffer. Journal of Soil and Water Conservation 58:1-8.

64 Dosskey, M.G., Helmers, M.J., Eisenhauer, D.E., Franti, T.G., and Hoagland, K.D. 2002. Assessment of concentrated flow through riparian buffers. Journal of Soil and Water Conservation 57:336-343.

$65 \mathrm{Sahu}, \mathrm{M}$. and Gu, R.R. 2009. Modeling the effects of riparian buffer zone and contour strips on stream water quality. Ecological Engineering 35:1167-1177.

66 Liu, X.M., Mang, X.Y., and Zhang, M.H. 2008. Major factors influencing the efficacy of vegetated buffers on sediment trapping: A review and analysis. Journal of Environmental Quality 37:1667-1674.

67 Zhang, X.Y., Liu, X.M., Zhang, M.H., Dahlgren, R.A., and Eitzel, M. 2010. A review of vegetated buffers and a 
meta-analysis of their mitigation rfficacy in reducing nonpoint source pollution. Journal of Environmental Quality 39:76-84.

68 Schmitt, T.J., Dosskey, M.G., and Hoagland, K.D. 1999. Filter strip performance and processes for different vegetation, widths, and contaminants. Journal of Environmental Quality 28:1479-1489.

69 Abu-Zreig, M., Rudra, R.P., Lalonde, M.N., Whiteley, H.R., and Kaushik, N.K. 2004. Experimental investigation of runoff reduction and sediment removal by vegetated filter strips. Hydrological Processes 18:2029-2037.

70 Mayer, P.M., Reynolds, S.K. Jr, McCutchen, M.D., and Canfield, T.J. 2007. Meta-analysis of nitrogen removal in riparian buffers. Journal of Environmental Quality 36:1172-1180.

71 Zhou, X., Helmers, M.J., Asbjornsen, H., Kolka, R., and Tomer, M.D. 2010. Perennial filter strips reduce nitrate levels in soil and shallow groundwater after grasslandto-cropland conversion. Journal of Environmental Quality 39:2006-2015.

72 Patty, L., Real, B., and Gril, J.J. 1997. The use of grassed buffer strips to remove pesticides, nitrate and soluble phosphorus compounds from runoff water. Pesticide Science 49:243-251.

73 Jiang, P., Anderson, S.H., Kitchen, N.R., Sadler, E.J., and Sudduth, K.A. 2007. Landscape and conservation management effects on hydraulic properties of a claypan-soil toposequence. Soil Science Society of America Journal 71:803-811.

74 Tomer, M.D., James, D.E., and Isenhart, T.M. 2003. Optimizing the placement of riparian practices in a watershed using terrain analysis. Journal of Soil and Water Conservation 58:198-206.

75 McGee, E.A., Peterson, G.A., and Westfall, D.G. 1997. Water storage efficiency in no-till dryland cropping systems. Journal of Soil and Water Conservation 52:131-136.

76 Tomer, M.D., Dosskey, M.G., Burkart, M.R., James, D. E., Helmers, M.J., and Eisenhauer, D.E. 2009. Methods to prioritize placement of riparian buffers for improved water quality. Agroforestry Systems 75:17-25.

77 Yang, W.H. and Weersink, A. 2004. Cost-effective targeting of riparian buffers. Canadian Journal of Agricultural Economics-Revue Canadienne D Agroeconomie 52:17-34.

78 Geza, M., Barfield, B.J., Huhnke, R.L., Stoecker, A., Storm, D.E., and Stevens, E.W. 2009. Comparison of targeted replacement and vegetative filter strips for sediment control and cost effectiveness. Journal of Water Resources Planning and Management 135:406-409.

79 Qiu, Z. 2009. Assessing critical source areas in watersheds for conservation buffer planning and riparian restoration. Environmental Management 44:968-980.

80 Wu, J.Y., Huang, D., Teng, W.J., and Sardo, V.I. 2010. Grass hedges to reduce overland flow and soil erosion. Agronomy for Sustainable Development 30:481-485.

81 Belden, J.B. and Coats, J.R. 2004. Effect of grasses on herbicide fate in the soil column: infiltration of runoff, movement, and degradation. Environmental Toxicology and Chemistry 23:2251-2258.

82 Smith, K.E., Putnam, R.A., Phaneuf, C., Lanza, G.R., Dhankher, O.P., and Clark, J.M. 2008. Selection of plants for optimization of vegetative filter strips treating runoff from turfgrass. Journal of Environmental Quality 37:18551861.

83 Meyer, L.D., Dabney, S.M., and Harmon, W.C. 1995. Sediment-trapping effectiveness of stiff-grass hedges. Transactions of the ASAE 38:809-815.

84 Wilson, H.M., Cruse, R.M., and Burras, C.L. 2011. Perennial grass management impacts on runoff and sediment export from vegetated channels in pulse flow runoff events. Biomass and Bioenergy 35:429-436.

85 Brye, K.R., Norman, J.M., Bundy, L.G., and Gower, S.T. 2000. Water-budget evaluation of prairie and maize ecosystems. Soil Science Society of America Journal 64(2):715-724.

86 Daniels, R.B. and Gilliam, J.W. 1996. Sediment and chemical load reduction by grass and riparian filters. Soil Science Society of America Journal 60:246-251.

87 Udawatta, R.P., Krstansky, J.J., Henerson, G.S., and Garrett, H.E. 2002. Agroforestry practices, runoff, and nutrient loss: a paired watershed comparison. Journal of Environmental Quality. 31:1214-1225.

88 Veum, K.S., Goyne, K.W., Motavalli, P.P., and Udawatta, R.P. 2009. Runoff and dissolved organic carbon loss from a paired-watershed study of three adjacent agricultural Watersheds. Agriculture, Ecosystems and Environment 130:115-122.

89 Gajic, B., Dugalic, G., Sredojevic, Z., and Tomic, Z. 2008. Effect of different vegetation types on infiltration and soil water retention. Cereal Research Communications 36:991-994.

90 Jose, S., Gillespie, A.R., and Pallardy, S.G. 2004. Interspecific interactions in temperate agroforestry. Agroforestry Systems 61:237-255.

91 Kumar, B.M. and Nair, P.K.R. 2004. The enigma of tropical homegardens. Agroforestry Systems 61:135152.

92 Godsey, S. and Elsenbeer, H. 2002. The soil hydrologic response to forest regrowth: a case study from southwestern Amazonia. Hydrological Processes 16:1519-1522.

93 Hanson, D.L., Steenhuis, T.S., Walter, M.F., and Boll, J. 2004. Effects of soil degradation and management practices on the surface water dynamics in the Talgua River Watershed in Honduras. Land Degradation and Development 15:367-381.

94 Zimmermann, B., Elsenbeer, H., and De Moraes, J.M. 2006. The influence of land-use changes on soil hydraulic properties: implications for runoff generation. Forest Ecology and Management 222:29-38.

95 Muschler, R.G. and Bonnemann, A. 1997. Potentials and limitations of agroforestry for changing land-use in the tropics: experiences from Central America. Forest Ecology and Management 91:61-73.

96 Perfecto, I., Rice, R.A., Greenberg, R., and Van Der Voort, M.E. 1996. Shade coffee: a disappearing refuge for biodiversity: shade coffee plantations can contain as much biodiversity as forest habitats. Bioscience 46:598-608.

97 Lindsay, J. and Rocha, L.B. 2009. A fast-changing landscape for fuel ethanol? International Sugar Journal 111:150-155.

98 Thomlinson, J.R., Serrano, M.I., Lopez, T.D., Aide, T.M., and Zimmerman, J.K. 1996. Land-use dynamics in a post-agricultural Puerto Rican landscape (1936-1988). Biotropica 28:525-536. 
99 Danielsen, F., Beukema, H., Burgess, N.D., Parish, F., Bruhl, C.A., Donald, P.F., Murdiyarso, D., Phalan, B., Reijnders, L., Struebig, M., and Fitzherbert, E.B. 2008. Biofuel plantations on forested lands: double jeopardy for biodiversity and climate. Conservation Biology 23:348-358

100 Martinez, M.L., Perez-Maqueo, O., Vazquez, G., CastilloCampos, G., Garcia-Franco, J., Mehltreter, K., Equihua, M., and Landgrave, R. 2009. Effects of land use change on biodiversity and ecosystem services in tropical montane cloud forests of Mexico. Forest Ecology and Management 258:1856-1863.

101 Zhang, S., Kang, S., and Zhang, K. 2004. Effect of soil and water conservation on the runoff on the Loess Plateau. Transactions of the Chinese Society of Agricultural Engineering 20:56-59.

102 Farley, K.A., Jobbagy, E.G., and Jackson, R.B. 2005. Effects of afforestation on water yield: a global synthesis with implications for policy. Global Change Biology. 11:1565-1576.

103 Yang, X., Zhang, K., Jia, B., and Ci, L. 2005. Desertification assessment in China: an overview. Journal of Arid Environments 63:517-531.

104 Wilske, B., Lu, N., Wei, L., Chen, S., Zha, T., Liu, C., Xu, W., Noormets, A., Huang, J., Wei, Y., Chen, J., Zhang, Z., Ni, J., Sun, G., Guo, K., McNulty, S., John, R., Han, X., Lin, G., and Chen, J. 2009. Poplar plantation has the potential to alter the water balance in semiarid Inner Mongolia. Journal of Environmental Management 90:2762-2770.

105 Casson, A. 1997. The Controversy Surrounding Eucalypts in Social Forestry Programs of Asia. Australian National University, Canberra.

106 Illstedt, U., Malmer, A., Elke, V., and Murdiyarso, D. 2007. The effect of afforestation on water infiltration in the tropics: a systematic review and meta-analysis. Forest Ecology and Management 251:45-51.

107 Davidson, J. 1995. Ecological aspects of Eucalyptus plantations. In Proceedings of the Regional Expert Consultation on Eucalyptus, RAPA Publication, Bangkok, Thailand, vol. 1, p. 35-60.

108 Oyedele, D.J., Awotoye, O.O., and Popoola, S.E. 2009. Soil physical and chemical properties under continuous maize cultivation as influenced by hedgerow tree species on an alfisol in South Western Nigeria. African Journal of Agricultural Research 4(8):736-739.

109 Hansson, L. 2006. Comparisons of Infiltration Capacities in Different Parklands and Farming Systems of Semi-Arid Burkina Faso. Forest Ecology. Swedish University of Agricultural Science, Uppsala, Sweden.

110 Torquebiau, E.F. and Kwesiga, F. 1996. The role of roots in improved fallows systems in eastern Zambia. Agroforestry Systems 34:193-211.

111 Gebresamuel, G., Singh, B.R., and Dick, Ø.B. 2010. Landuse changes and their impacts on soil degradation and surface runoff of two catchments of Northern Ethiopia. Acta Agriculturae Scandinavia Section B: Soil and Plant Science 60:211-226.

112 Rao, M.R., Mafongoya, P.L., Kwesiga, F.R., and Maghembe, J.A. 1999. Nutrient cycling in agroforestry systems of the semi-arid tropics of Africa. Annals of Arid Zone 38(3-4):275-307.
113 Sanou, J., Zougmore, R., Bayala, J., and Teklehaimonot, Z. 2010. Soil infiltrability and water content as affected by Baobab (Adansonia digitata L.) and Nere (Parkia biglobosa (Jacq.) Benth.) trees in farmed parklands of West Africa. Soil Use and Management 26(1):75-81.

114 Kho, R.M., Yacouba, B., Yaye, M., Katkore, B., Moussa, A., Iktam, A., and Mayaki, A. 2001. Separating the effects of trees on crops: the case of Faidherbia albida and millet in Niger. Agroforestry Systems 52(3):219-238.

115 Bayala, J., Heng, L.K., van Noordwijk, M., and Ouedraogo, S.J. 2008. Hydraulic lift study in two native tree species of agroforestry parklands of West African dry savanna. Acta Oecolgia 34:370-378.

116 Larwanou, M., Lee, K.H., and Abdou, R. 2005. Hydraulic lift study in two native tree species in agroforestry parkland of the West African dry savanna: Faidherbia albida (Del.) A. Chev. and Prosopis africana (Guil). Rapport final du contrat de recherche avec l'Agence Internationale de l'Energie atomique (AIEA).

117 Ludwig, F., Dawson, T.E., de Kroon, H., Berendse, F., and Prins, H.H.T. 2003. Hydraulic lift in Acacia tortilis trees on an East African savanna. Oecologia 134:293-300.

118 Garrity, D.P., Akinnifesi, F.K., Ajayi, O.C., Weldesemayat, S.G., Mowo, J.G., Kalinganire, A., Larwanou, M., and Bayala, J. 2010. Evergreen agriculture: a robust approach to sustainable food security in Africa. Food Security 2:197-214.

119 Syampungani, S., Chirwa, P.W., Akinnifesi, F.K., and Ajayi, O.C. 2010. The potential of using agroforestry as a win-win solution to climate change mitigation and adaptation and meeting food security challenges in Southern Africa. Agricultural Journal 5:80-88.

120 Qiao, C., Chen, Y., Hong, M., Li, S., and Liu, A. 2004. Sand fixation effect of annual crops mixed with perennial ammodyte cross-line. Journal of Inner Mongolia Agricultural Unviersity 25:98-101.

121 Zhao, C., Shanm, L., Deng, X., Zhao, L., Zhang, Y., and Wang, S. 2004. Current situation and counter-measure of the development of dryland farming in China. Transactions of the CSAE 20:280-285.

122 Wang, X.H., Yin, C.Q., and Shan, B.Q. 2004. Control of diffuse p-pollutants by multiple buffer/detention structures by Yuqiao Reservoir, North China. Journal of Environmental Sciences-China 16:616-620.

123 Guo, L.-P., Huang, L.-Q., Jiang, Y.-X., and Lv, D.-M. 2006. Prevention of soil deterioration during cultivation of medicinal plants. China Journal of Chinese Materia Medica 31:714-717.

124 Xin, N.Q. 2000. The important progress and some strategic suggestions on the west China's dryland and agricultural science and technology. Journal of China Agricultural Resources and Regional Planning 21:27-31.

125 Bao, J.C., Wu, G.Q., and Zhang, G.X. 2006. Herbicides from green plants and their applications. Forest By-Product and Specialty in China 3:69-72.

126 Gordon, L.J., Peterson, G.D., and Bennett, E.M. 2008. Agricultural modifications of hydrological flows create ecological surprises. Trends in Ecology and Evolution 23:211-219.

127 Pan, C., Ma, L., and Shangguan, Z. 2010. Effectiveness of grass strips in trapping suspended sediments from runoff. Earth Surface Processes and Landforms 35:1006-1013. 
128 Wang, X.H., Yin, C.Q., and Shan, B.Q. 2005. The role of diversified landscape buffer structures for water quality improvement in an agricultural watershed, North China. Agriculture, Ecosystems and Environment 107:381-396.

129 Dass, A., Sudhishri, S., Lenka, N.K., and Patnaik, U.S. 2011. Runoff capture through vegetative barriers and planting methodologies to reduce erosion, and improve soil moisture, fertility and crop productivity in southern Orissa, India. Nutrient Cycling in Agroecosystems 89:45-57.

130 Vigiak, O., Ribolzi, O., Pierret, A., Sengtaheuanghoung, O., and Valentin, C. 2008. Trapping efficiencies of cultivated and natural riparian vegetation of northern Laos. Journal of Environmental Quality 37:889-897.

131 Canadell, J.G., Le Quere, C., Raupach, M.R., Field, C.B., Buitenhuis, E.T., Ciais, P., Conway, T.J., Gillett, N.P., Houghton, R.A., and Marland, G. 2007. Contributions to accelerating atmospheric $\mathrm{CO}(2)$ growth from economic activity, carbon intensity, and efficiency of natural sinks. Proceedings of the National Academy of Sciences of the United States of America 104:18866-18870.

132 Grace, P.R., Robertson, G.P., Millar, N., Colunga-Garcia, M., Basso, B., Gage, S.H., and Hoben, J. 2011. The contribution of maize cropping in the Midwest USA to global warming: a regional estimate. Agricultural Systems 104:292-296.

133 Bailey, N., Motavalli, P., Udawatta, R., and Nelson, K. 2009. Soil $\mathrm{CO}_{2}$; emissions in agricultural watersheds with agroforestry and grass contour buffer strips. Agroforestry Systems 77:143-158.

134 Tolbert, V.R., Todd, D.E., Mann, L.K., Jawdy, C.M., Mays, D.A., Malik, R., Bandaranayake, W., Houston, A., Tyler, D., and Pettry, D.E. 2002. Changes in soil quality and below-ground carbon storage with conversion of traditional agricultural crop lands to bioenergy crop production. Environmental Pollution 116:S97-S106.

135 Jelinski, N.A. and Kucharik, C.J. 2009. Land-use effects on soil carbon and nitrogen on a US midwestern floodplain. Soil Science Society of America Journal 73:217-225.

136 Knops, J.M.H. and Tilman, D. 2000. Dynamics of soil nitrogen and carbon accumulation for 61 years after agricultural abandonment Ecology 81:88-98.

137 Kucharik, C.J., Brye, K.R., Norman, J.M., Foley, J.A., Gower, S.T., and Bundy, L.G. 2001. Measurements and modeling of carbon and nitrogen cycling in agroecosystems of southern Wisconsin: potential for SOC sequestration during the next 50 years. Ecosystems 4:237-258.

138 West, T.O. and Post, W.M. 2002. Soil organic carbon sequestration rates by tillage and crop rotation: a global data analysis. Soil Science Society of America Journal 66:1930-1946.

139 Baer, S.G., Rice, C.W., and Blair, J.M. 2000. Assessment of soil quality in fields with short and long term enrollment in the CRP. Journal of Soil and Water Conservation 55:142-146.

140 Grandy, A.S. and Robertson, G.P. 2007. Land-use intensity effects on soil organic carbon accumulation rates and mechanisms. Ecosystems 10:58-73.

141 Jastrow, J.D. 1996. Soil aggregate formation and the accrual of particulate and mineral-associated organic matter. Soil Biology and Biochemistry 28:665-676.
142 McLauchlan, K. 2006. The nature and longevity of agricultural impacts on soil carbon and nutrients: a review. Ecosystems 9:1364-1382.

143 Post, W.M. and Kwon, K.C. 2000. Soil carbon sequestration and land-use change: processes and potential. Global Change Biology 6:317-327.

144 Schlesinger, W.H. 1990. Evidence from chronosequence studies for a low carbon-storage potential of soils. Nature 348:232-234.

145 Matamala, R., Jastrow, J.D., Miller, R.M., and Garten, C.T. 2008. Temporal changes in $\mathrm{C}$ and $\mathrm{N}$ stocks of restored prairie: implications for $\mathrm{C}$ sequestration strategies. Ecological Applications 18:1470-1488.

146 Culman, S.W., DuPont, S.T., Glover, J.D., Buckley, D.H., Fick, G.W., Ferris, H., and Crews, T.E. 2010. Long-term impacts of high-input annual cropping and unfertilized perennial grass production on soil properties and belowground food webs in Kansas, USA. Agriculture, Ecosystems and Environment 137:13-24.

147 Wilson, B.R., Barnes, P., Koen, T.B., Ghosh, S., and King, D. 2010. Measurement and estimation of land-use effects on soil carbon and related properties for soil monitoring: a study on a basalt landscape of northern New South Wales, Australia. Australian Journal of Soil Research 48:421-433.

148 Sequin, B., Arrouays, D., Balesdent, J., Soussana, J.F., Bondeau, A., Smith, P., Zaehle, S., de Noblet, N., and Viovy, N. 2007. Moderating the impact of agriculture on climate. Agricultural and Forest Meteorology 142:278-287.

149 Gelfand, I., Zenone, T., Jasrotia, P., Chen, J., Hamilton, S.K., and Robertson, G.P. 2011. Carbon debt of a CRP grassland converted to bioenergy production. Proceedings of National Academy of Sciences of the United States of America 108:13864-13869.

150 Weaver, J.E. 1920. Root Development in the Grassland Formation. Carnegie Institution of Washington, Washington DC.

151 Aguilar, R., Kelly, E.F., and Heil, R.D. 1988. Effects of cultivation on soils in northern Great Plains rangeland. Soil Science Society of America Journal 52:1081-1085.

152 Pennock, D.J. and van Kessel, C. 1997. Effect of agriculture and of clear-cut forest harvest on landscape-level soil organic carbon storage in Saskatchewan. Canadian Journal of Soil Science 77:211-218.

153 De Deyn, G.B., Quirk, H., Yi, Z., Oakley, S., Ostle, N.J., and Bardgett, R.D. 2009. Vegetation composition promotes carbon and nitrogen storage in model grassland communities of contrasting soil fertility. Journal of Ecology 97:864-875.

154 Fornara, D.A. and Tilman, D. 2008. Plant functional composition influences rates of soil carbon and nitrogen accumulation. Journal of Ecology 96:314-322.

155 Peichl, M., Thevathasan, N.V., Gordon, A.M., Huss, J., and Abohassan, R.A. 2006. Carbon sequestration potentials in temperate tree-based intercropping systems, southern Ontario, Canada. Agroforestry Systems 66:243-257.

156 Bashkin, M.A. and Binkley, D. 1998. Changes in soil carbon following afforestation in Hawaii. Ecology 79:828-833.

157 Laungani, R. and Knops, J.M.H. 2009. The impact of co-occurring tree and grassland species on carbon 
sequestration and potential biofuel production. Global Change Biology Bioenergy 1:392-403.

158 Wolters, V., Silver, W.L., Bignell, D.E., Coleman, D.C., Lavelle, P., Van der Putten, W.H., de Ruiter, P., Rusek, J., Wall, D.H., Wardle, D.A., Brussaard, L., Dangerfield, J.M., Brown, V.K., Giller, K.E., Hooper, D.U., Sala, O., Tiedje, J., and van Veen, J.A. 2000. Effects of global changes on above- and belowground biodiversity in terrestrial ecosystems: implications for ecosystem functioning. BioScience 50:1089-1098.

159 Knapp, A.K. 1993. Gas-exchange dynamics in C-3 and C-4 grasses - Consequences of differences in stomatal conductance. Ecology 74:113-123.

160 Knapp, A.K., Briggs, J.M., Blair, J.M., and Turner, C.L. 1998. Patterns and controls of aboveground net primary productivity in tallgrass prairie. In A.K. Knapp, J.M. Briggs, D.C. Hartnett, and S. Collins (eds). Grassland Dynamics: Long-term Ecological Research in Tallgrass Prairie. Oxford University Press, New York, p. 193-221.

161 Nippert, J.B., Fay, P.A., Carlisle, J.D., Knapp, A.K., and Smith, M.D. 2009. Ecophysiological responses of two dominant grasses to altered temperature and precipitation regimes. Acta Oecologica-International Journal of Ecology 35:400-408.

162 Novoplansky, A. and Goldberg, D. 2001. Interactions between neighbour environments and drought resistance. Journal of Arid Environments 47:11-32.

$163 \mathrm{Xu}$, L.K. and Baldocchi, D.D. 2004. Seasonal variation in carbon dioxide exchange over a Mediterranean annual grassland in California. Agricultural and Forest Meteorology 123:79-96.

164 Tufekcioglu, A., Raich, J.W., Isenhart, T.M., and Schultz, R.C. 1998. Fine root dynamics, coarse root biomass, root distribution, and soil respiration in a multispecies riparian buffer in Central Iowa, USA. Agroforestry Systems 44:163-174.

165 Weaver, J.E. 1958. Classification of root systems of forbs of grassland and a consideration of their significance. Ecology 39:393-401.

166 Asbjornsen, H., Mora, G., and Helmers, M.J. 2007. Variation in water uptake dynamics among contrasting agricultural and native plant communities in the Midwestern US. Agriculture, Ecosystems and Environment 121:343-356.

167 Hayes, D.C. and Seastedt, T.R. 1986. Root dynamics of tallgrass prairie in wet and dry years. Canadian Journal Botany 65:787-791.

168 Nippert, J.B. and Knapp, A.K. 2007. Soil water partitioning contributes to species coexistence in tallgrass prairie. Oikos 116:1017-1029.

169 van Nes, E.H. and Scheffer, M. 2005. Implications of spatial heterogeneity for catastrophic regime shifts in ecosystems. Ecology 86:1797-1807.

170 Benjamin, J.G. and Nielsen, D.C. 2006. Water deficit effects on root distribution of soybean, field pea and chickpea. Field Crops Research 97:248-253.

171 Challinor, A.J., Wheeler, T.R., Slingo, J.M., and Hemming, D. 2005. Quantification of physical and biological uncertainty in the simulation of the yield of a tropical crop using present-day and doubled $\mathrm{CO}_{2}$ climates. Philosophical Transactions of the Royal Society B: Biological Sciences 360:2085-2094.
172 Porter, J.R. and Semenov, M.A. 2005. Crop responses to climatic variation. Philosophical Transactions of the Royal Society B: Biological Sciences 360:2021-2035.

173 Slingo, J.M., Challinor, A.J., Hoskins, B.J., and Wheeler, T.R. 2005. Introduction: food crops in a changing climate. Philosophical Transactions of the Royal Society B: Biological Sciences 360:1983-1989.

174 Traore, S.B., Carlson, R.E., Pilcher, C.D., and Rice, M.E. 2000. Bt and non-Bt maize growth and development as affected by temperature and drought stress. Agronomy Journal 92:1027-1035.

175 Hooper, D.U. and Vitousek, P.M. 1998. Effects of plant composition and diversity on nutrient cycling. Ecological Monographs 68:121-149.

176 Naeem, S. and Li, S.B. 1997. Biodiversity enhances ecosystem reliability. Nature 390:507-509.

177 De Boeck, H.J., Lemmens, C.M.H.M., Bossuyt, H., Malchair, S., Carnol, M., Merckx, R., Nijs, I., and Ceulemans, R. 2006. How do climate warming and plant species richness affect water use in experimental grasslands? Plant and Soil 288:249-261.

178 Morecroft, M.D., Masters, G.J., Brown, V.K., Clarke, I.P., Taylor, M.E., and Whitehouse, A.T. 2004. Changing precipitation patterns alter plant community dynamics and succession in an ex-arable grassland. Functional Ecology 18:648-655.

179 Salinger, M.J., Sivakumar, M.V.K., and Motha, R. 2005. Reducing vulnerability of agriculture and forestry to climate variability and change: workshop summary and recommendations. Climatic Change 70:341-362.

180 Van Peer, L., Nijs, I., Reheul, D., and De Cauwer, B. 2004. Species richness and susceptibility to heat and drought extremes in synthesized grassland ecosystems: compositional vs physiological effects. Functional Ecology 18:769-778.

181 Swift, M.J., Izac, A.M.N., and van Noordwijk, M. 2004. Biodiversity and ecosystem services in agricultural landscapes-are we asking the right questions? Agriculture, Ecosystems and Environment 104:113-134.

182 DeFries, R. and Rosenzweig, C. 2010. Toward a wholelandscape approach for sustainable land use in the tropics. Proceedings of the National Academy of Sciences of the United States of America 107:19627-19632.

183 Gibbs, H.K., Brown, S., Niles, J.O., and Foley, J.A. 2007. Monitoring and estimating tropical forest carbon stocks: making REDD a reality. Environmental Research Letters 4(2):04523.

184 Segura, M., Kanninen, M., and Suarez, D. 2006. Allometric models for estimating aboveground biomass of shade trees and coffee bushes grown together. Agroforestry Systems 68:143-150.

185 Soto-Pinto, L., Anzueto, M., Mendoza, J., Ferrer, G., and de Jong, B. 2010. Carbon sequestration through agroforestry in indigenous communities of Chiapas, Mexico. Agroforestry Systems 78:39-51.

186 Kirby, K.R. and Potvin, C. 2007. Variation in carbon storage among tree species: implications for the management of a small-scale carbon sink project. Forest Ecology and Management 246:208-221.

187 Laganiere, J., Angers, D.A., and Pare, D. 2010. Carbon accumulation in agricultural soils after afforestation: a meta-analysis. Global Change Biology 16:439-453. 
188 Berndes, G. 2002. Bioenergy and water-the implications of large-scale bioenergy production for water use and supply. Global Environmental Change-Human and Policy Dimensions 12:253-271.

189 Bayala, J., Balesdent, J., Marol, C., Zapata, F., Teklehaimanot, Z., and Ouedraogo, S.J. 2006. Relative contribution of trees and crops to soil carbon content in a parkland system in Burkina Faso using variations in natural C-13 abundance. Nutrient Cycling in Agroecosystems 76:193-201.

190 Jonsson, K. 1995. Agroforestry in Dry Savanna Areas in Africa: Interactions between Trees, Soils and Crops. Swedish University of Agricultural Sciences, Umea, Sweden.

191 Takimoto, A., Nair, P.K.R., and Nair, V.D. 2008. Carbon stock and sequestration potential of traditional and improved agroforestry systems in the West African Sahel. Agriculture Ecosystems and Environment 125:159-166.

192 Kaonga, M.L. and Bayliss-Smith, T.P. 2009. Carbon pools in tree biomass and the soil in improved fallows in eastern Zambia. Agroforestry Systems 76:37-51.

193 Lal, R. 2010. Beyond Copenhagen: mitigating climate change and achieving food security through soil carbon sequestration. Food Security 2:169-177.

194 Makumba, W., Akinnifesi, F.K., Janssen, B., and Oenema, O. 2007. Long-term impact of a gliricidia-maize intercropping system on carbon sequestration in southern Malawi. Agriculture, Ecosystems and Environment 118:237-243.

195 Bayala, J., Teklehaimanot, Z., and Ouedraogo, S.J. 2002. Millet production under pruned tree crowns in a parkland system in Burkina Faso. Agroforestry Systems 54:203-214.

196 Lamien, N., Sidibé, A., and Bayala, J. 1996. Use and commercialization of non-timber forest products in western Burkina Faso. In R.R.B. Leakey, A.B. Temu, and M. Melnyk (eds). Domestication and Commercialization of Non-Timber Forest Products in Agroforestry Systems. FAO, Rome, Italy. p. 51-63.

197 Jonsson, K., Ong, C.K., and Odongos, J.C.W. 1999. Influence of scattered néré and karité on microclimate, soil fertility and millet yield in Burkina Faso. Experimental Agriculture 35:39-53.

198 Lin, B.B. 2007. Agroforestry management as an adaptive strategy against potential microclimate extremes in coffee agriculture. Agricultural and Forest Meteorology 144:85-94.

199 Hutchinson, J.J., Campbell, C.A., and Desjardins, R.L. 2006. Some perspectives on carbon sequestration in agriculture. Agriculture, Ecosystems and Environment 142:288-302.

200 Ogle, S.M., Breidt, F.J., and Paustian, K. 2005. Agricultural management impacts on soil organic carbon storage under moist and dry climatic conditions of temperate and tropical regions. Biogeochemistry 72:87121.

201 West, P.C., Gibbs, H.K., Monfreda, C., Wagner, J., Barford, C.C., Carpenter, S.R., and Foley, J.A. 2010. Trading carbon for food: global comparison of carbon stocks vs. crop yields on agricultural land. Proceedings of the National Academy of Sciences of the United States of America 107:19645-19648.
202 Laird, D.A. 2008. The charcoal vision: a win-win scenario for simultaneously producing bioenergy, permanently sequestering carbon, while improving soil and water quality. Agronomy Journal 100(1):178-181.

203 Atkinson, C.J., Fitzgerald, J.D., and Hipps, N.A. 2010. Potential mechanisms for achieving agricultural benefits from biochar application to temperate soils: a review. Plant and Soil 337:1-18.

204 Fiedler, A.K., Landis, D.A., and Wratten, S.D. 2008. Maximizing ecosystem services from conservation biological control: the role of habitat management. Biological Control 45:254-271.

205 Pluess, T., Opatovsky, I., Gavish-Regev, E., Lubin, Y., and Schmidt-Entling, M.H. 2010. Non-crop habitats in the landscape enhance spider diversity in wheat fields of a desert agroecosystem. Agriculture. Ecosystems and Environment 137:68-74.

206 Bianchi, F., Booij, C., and Tscharntke, T. 2006. Sustainable pest regulation in agricultural landscapes: a review on landscape composition, biodiversity and natural pest control. Proceedings of the Royal Society B 273:1715-1727.

207 Werling, B.P., Harmon, J., Straub, C., and Gratton, C. 2012. Influence of native North American prairie grasses on predation of an insect herbivore of potato. Biological Control 61:15-25.

208 Landis, D.A., Wratten, S.D., and Gurr, G.M. 2000. Habitat management to conserve natural enemies of arthropod pests in agriculture. Annual Review of Entomology 45:175-201.

209 Gurr, G.M., Wratten, S.D., and Luna, J.M. 2003. Multifunction agricultural biodiversity: pest management and other benefits. Basic and Applied Ecology 4:107-116.

210 Jervis, M.A., Lee, J.C., and Heimpel, G.E. 2004. Use of behavioural and life-history studies to understand the effects of habitat manipulation. In G.M. Gurr, S.D. Wratten, and M.A. Altieri (eds). Ecological Engineering for Pest Management: Advances in Habitat Manipulation for Arthropods. Comstock Publishing Associates, Ithaca, NY. p. 65-100.

211 Marshall, E.J.R. and Moonen, A.C. 2002. Field margins in northern Europe: their functions and interactions with agriculture. Agriculture, Ecosystems and Environment 89:5-21.

212 Woltz, J.M., Isaacs, R., and Landis, D.A. 2012. Landscape structure and habitat management differentially influence insect natural enemies in an agricultural landscape. Agriculture, Ecosystems and Environment 152: 40-49.

213 Bianchi, F.J.J.A., van Wingerden, W.K.R.E., Griffioen, A.J., van der Veen, M., van der Straten, M.J.J., Wegman, R.M.A., and Meeuwsen, H.A.M. 2005. Landscape factors affecting the control of Mamestra brassicae by natural enemies in Brussels sprout. Agriculture, Ecosystems and Environment 107:145-150.

214 Thies, C. and. Tscharntke, T. 1999. Landscape structure and biological control of agroecosystems. Science 285:893-895.

215 Tscharntke, T., Steffan-Dewenter, I., Kruess, A., and Thies, C. 2002. Contribution of small habitat fragments to conservation of insect communities of grassland-cropland landscapes. Ecological Applications 12:354-363. 
216 Gardiner, M.M., Landis, D.A., Gratton, C., DiFonzo, C.D., O’Neal, M., Chacon, J., Wayo, M., Schmidt, N., Mueller, E., and Heimpel, G.E. 2009. Landscape diversity enhances biological control of an introduced crop pest in the north-central U.S. Ecological Applications 19:143-154.

217 Klein, A.M., Cunningham, S.A., Bos, M., and SteffanDewenter, I. 2007. Advances in pollination ecology from tropical plantation crops. Ecology 89:935-943.

218 Grixti, J.C., Wong, L.T., Cameron, S.C., and Favret, C. 2009. Decline of bumble bees in the 122 North American Midwest. Biological Conservation 142:75-84.

219 Grundel, R., Jean, R.P., Frohnapple, K.J., Glowacki, G.A., Scott, P.E., and Pavlovic, N.B. 2010. Floral and nesting resources, habitat structure, and the influence of bee distribution across an open-forest gradient. Ecological Applications 20:1678-1692.

220 Hendrix, S.D., Kwaiser, K.S., and Heard, S.B. 2010. Bee communities (Hymenoptera: Apoidea) of small Iowa hill prairies are as diverse and rich as those of large prairie preserves. Biodiversity and Conservation 19:1699-1709.

221 Bugg, R.L. 1992. Using cover crops to manage arthropods on truck farms. HortScience 27:741-745.

222 Bugg, R.L. and Waddington, C. 1994. Using cover crops to manage arthropod pests of orchards: a review. Agriculture, Ecosystems and Environment 50:11-28.

223 Prasifka, J.R., Schmidt, N.P., Kohler, K.A., O’Neal, M.E., Hellmich, R.L., and Singer, J.W. 2006. Effects of living mulches on predator abundance and sentinel prey in a corn-soybean-forage rotation. Environmental Entomology 35:1423-1431.

224 Schmidt, N.P., O’Neal, M.E., and Singer, J.W. 2007. Alfalfa living mulch advances biological control of soybean aphid. Environmental Entomology 36:416-424.

225 Collins, K.L., Boatman, N.D., Wilcox, A., Holland, J.M., and Chaney, K. 2002. Influence of beetle banks on cereal aphid predation in winter wheat. Agriculture, Ecosystems and Environment 93:337-350.

226 MacLeod, A., Wratten, S.D., Sotherton, N.W., and Thomas, M.B. 2004. 'Beetle banks' as refuges for beneficial arthropods in farmland: long-term changes in predator communities and habitat. Agricultural and Forest Entomology 6:147-154.

227 Nicholls, C.I., Parrella, M.P., and Altieri, M.A. 2001. The effects of a vegetational corridor on the abundance and dispersal of insect biodiversity within a northern California organic vineyard. Landscape Ecology 16:133-146.

228 Mensah, R.K. and Sequeira, R.V. 2004. Habitat manipulation for insect pest management in cotton cropping systems. In G.M. Gurr, S.D. Wratten, and M.A. Altieri (eds). Ecological Engineering for Pest Management. CSIRO Publishing, Australia and CABI Publishing, UK. p. $187-197$.

229 Lee, J.C., Menalled, F.B., and Landis, D.A. 2001. Refuge habitats modify impact of insecticide disturbance on carabid beetle communities. Journal of Applied Ecology 38:472-483.

230 Knops, J.M.H., Tilman, D., Haddad, N.M., Naeem, S., Mitchell, C.E., Haarstad, J., Ritchie, M.E., Howe, K.M., Reich, P.B., Siemann, E., and Groth, J. 1999. Effects of plant species richness on invasion dynamics, disease outbreaks, insect abundances and diversity. Ecology Letters 2:286-293.

231 Finckh, M.R. and Wolfe, M.S. 2006. Diversification strategies. In B.M. Cooke, D.G. Jones, and K. Kaye (eds). The Epidemiology of Plant Diseases. Springer, Dordrecht, The Netherlands. p. 269-307.

232 Hayes, R.C., Newell, M.T., DeHaan, L.R., Murphy, K.M., Crane, S., Norton, M.R., Wade, L.J., Newberry, M., Fahim, M., Jones, S.S., Cox, T.S., and Larkin, P.J. 2012. Perennial cereal crops: an initial evaluation of wheat derivatives. Field Crops Research 133:68-89.

233 Cox, C.M., Garrett, K.A., and Bockus, W.W. 2005. Meeting the challenge of disease management in perennial grain cropping systems. Renewable Agriculture and Food Systems 20:15-24.

234 Givnish, T.J. 1999. On the causes of gradients in tropical tree diversity. Journal of Ecology 87:193-210.

235 Philpott, S.M. and Armbrecht, I. 2006. Biodiversity in tropical agroforests and the ecological role of ants and ant diversity in predatory function. Ecological Entomology 31:369-377.

236 Philpott, S.M., Perfecto, I., and Vandermeer, J. 2006. Effects of management intensity and season on arboreal ant diversity and abundance in coffee agroecosystems. Biodiversity and Conservation 15:139-155.

237 De la Mora, A., Livingston, G., and Philpott, S.M. 2008. Arboreal ant abundance and leaf miner damage in coffee agroecosystems in Mexico. Biotropica 40:742-746.

238 Johnson, M.D., Kellermann, J.L., and Stercho, A.M. 2010. Pest reduction services by birds in shade and sun coffee in Jamaica. Animal Conservation 13:140-147.

239 Kellermann, J.L., Johnson, M.D., Stercho, A.M., and Hackett, S.C. 2008. Ecological and economic services provided by birds on Jamaican blue mountain coffee farms. Conservation Biology 22:1177-1185.

240 Brosi, B.J., Daily, G.C., Shih, T.M., Oviedo, F., and Duran, G. 2008. The effects of forest fragmentation on bee communities in tropical countryside. Journal of Applied Ecology 45:773-783.

241 De Marco, P. and Coelho, F.M. 2004. Services performed by the ecosystem: forest remnants influence agricultural cultures' pollination and production. Biodiversity and Conservation 13:1245-1255.

242 Ricketts, T.H. 2004. Tropical forest fragments enhance pollinator activity in nearby coffee crops. Conservation Biology 18:1262-1271.

243 Girma, H., Rao, M.R., and Sithanantham, S. 2000. Insect pests and beneficial arthropods population under different hedgerow intercropping systems in semiarid Kenya. Agroforestry Systems 50:279-292.

244 Rao, M.R., Singh, M.P., and Day, R. 2000. Insect pest problems in tropical agroforestry systems: contributory factors and strategies for management. Agroforestry Systems 50:243-277.

245 Khan, Z.R., Pickett, J.A., van den Berg, J., Wadhams, L.J., and Woodcock, C.M. 2000. Exploiting chemical ecology and species diversity: stem borer and striga control for maize and sorghum in Africa. Pest Management Science 56:957-962.

246 Khan, Z.R., Midega, C.A.O., Hutter, N.J., Wilkins, R.M., and Wadhams, L.J. 2006. Assessment of the potential of Napier grass (Pennisetum purpureum) varieties as trap 
plants for management of Chilo partellus. Entomologia Experimentalis Et Applicata 119:15-22.

247 Menalled, F.D., Costamagna, A.C., Marino, P.C., and Landis, D.A. 2003. Temporal variation in the response of parasitoids to agricultural landscape structure. Agriculture, Ecosystems and Environment 96:29-35.

248 Ragsdale, D.W., Voegtlin, D.J., and O’Neil, R.J. 2004. Soybean aphid biology in North America. Annals of the Entomological Society of America 97:204-208.

249 Doran, J.W. and Parkin, T.B. 1994. Defining and assessing soil quality. In J.W. Doran, D.C. Coleman, D.F. Bezdicek, and B.A. Stewart (eds). Defining Soil Quality for a Sustainable Environment. Soil Science Society of America and American Society of Agronomy, Madison, WI. p. 3-21.

250 Karlen, D.L., Mausbach, M.J., Doran, J.W., Cline, R.G., Harris, R.F., and Schuman, G.E. 1997. Soil quality: a concept, definition, and framework for evaluation. Soil Science Society of America Journal 61:4-10.

251 Russell, A.E., Cambardella, C.A., Laird, D.A., Jaynes, D. B., and Meek, D.W. 2009. Nitrogen fertilizer effects on soil carbon balances in Midwestern U.S. agricultural systems. Ecological Applications 19:1102-1113.

252 Weil, R.R. and Magdoff, F. 2004. Significance of soil organic matter to soil quality and health. In F. Magdoff and R.R. Weil (eds). Soil Organic Matter in Sustainable Agriculture. CRC Press, Boca Raton, FL. p. $1-44$.

253 Fox, R.H. and Piekielek, W.P. 1988. Fertilizer N equivalence of alfalfa, birdsfoot trefoil, and red clover for succeeding corn crops. Journal of Production Agriculture 1:313-317.

254 Morris, T.F., Blackmer, A.M., and Elhout, N.M. 1993. Optimal rates of nitrogen-fertilization for 1st-year corn after alfalfa. Journal of Production Agriculture 6:344-350.

255 Russell, A.E., Laird, D.A., and Mallarino, A.P. 2006. Nitrogen fertilization and cropping system impacts on soil quality in midwestern mollisols. Soil Science Society of America Journal 70:249-255.

256 Gregorich, E.G., Drury, C.F., and Baldock, J.A. 2001. Changes in soil carbon under long-term maize in monoculture and legume-based rotation. Canadian Journal of Soil Science 81:21-31.

257 Gregorich, E.G., Rochette, P., VandenBygaart, A.J., and Angers, D.A. 2005. Greenhouse gas contributions of agricultural soils and potential mitigation practices in Eastern Canada. Soil and Tillage Research 83:53-72.

258 Randall, G.W., Huggins, D.R., Russelle, M.P., Fuchs, D.J., Nelson, W.W., and Anderson, J.L. 1997. Nitrate losses through subsurface tile drainage in conservation reserve program, alfalfa, and row crop systems. Journal of Environmental Quality 26:1240-1247.

259 Richards, P.W., Walsh, R.P.D., Baillie, I.C., and Greg-Smith, P. 1996. The Tropical Rain Forest: An Ecological Study. Cambridge University Press, Cambridge.

260 Schroth, G., Elias, M.E.A., Uguen, K., Seixas, R., and Zech, W. 2001. Nutrient fluxes in rainfall, throughfall and stemflow in tree-based land use systems and spontaneous tree vegetation of central Amazonia. Agriculture Ecosystems and Environment 87:37-49.
261 Babbar, L.I. and Zak, D.R. 1995. Nitrogen loss from coffee agroecosystems in Costa-Rica-Leaching and denitrification in the presence and absence of shade trees. Journal of Environmental Quality 24:227-233.

262 Beer, J., Muschler, R., Kass, D., and Somarriba, E. 1998. Shade management in coffee and cacao plantations. Agroforestry Systems 38:139-164.

263 Harmand, J.M., Avila, H., Dambrine, E., Skiba, U., de Miguel, S., Renderos, R.V., Oliver, R., Jimenez, F., and Beer, J. 2007. Nitrogen dynamics and soil nitrate retention in a Coffea arabica-Eucalyptus deglupta agroforestry system in Southern Costa Rica. Biogeochemistry $85: 125-139$.

264 Jaramillo-Botero, C., Santos, R.H.S., Fardim, M.P., Pontes, T.M., and Sarmiento, F. 2008. Litter production and potential nutrient input of native tree species in an agroforestry system at zona Da Mata, MG, Brazil. Revista Arvore 32:869-877.

265 Leon, Y.S.D., De Melo, E., Soto, G., Johnson-Maynard, J., and Lugo-Perez, J. 2006. Earthworm populations, microbial biomass and coffee production in different experimental agroforestry management systems in Costa Rica. Caribbean Journal of Science 42:397-409.

266 Belsky, A.J. 1994. Influences of trees on savanna productivity - tests of shade, nutrients, and tree-grass competition. Ecology 75:922-932.

267 Ong, C.K. and Leakey, R.R.B. 1999. Why tree-crop interactions in agroforestry appear at odds with tree-grass interactions in tropical savannahs. Agroforestry Systems 45:109-129.

268 Van Noordwijk, M. and Ong, C.K. 1999. Can ecosystem mimic hypotheses be applied to farms in African savannahs? Agroforestry Systems 45:131-158.

269 Yuan, Y., Bingner, R.L., and Locke, M.A. 2009. A review of effectiveness of vegetative buffers on sediment trapping in agricultural areas. Ecohydrology 2:321-336.

270 Naylor, R., Steinfeid, H., Falcon, W., Galloways, J., Smil, V., Bradford, E., Alder, J., and Mooney, H. 2005. Losing the links between livestock and land. Science 310:1621-1622.

271 Sulc, R.M. and Tracy, B.F. 2007. Integrated croplivestock systems in the US corn belt. Agronomy Journal 99:335-345.

272 Glover, J.D., Cox, C.M., and Reganold, J.P. 2007. Future farming: a return to roots? Scientific American 297:82-89.

273 Russelle, M.P., Entz, M.H., and Franzluebbers, A.J. 2007. Reconsidering integrated crop-livestock systems in North America. Agronomy Journal 99:325-334.

274 Cox, T.S., Bender, M., Picone, C., Van Tassel, D.L., Holland, J.B., Brummer, E.C., Zoeller, B.E., Paterson, A. H., and Jackson, W. 2002. Breeding perennial grain crops. Critical Reviews in Plant Science 21:59-91.

275 Cox, T.S., Glover, J.D., Van Tassel, D.L., Cox, C.M. and DeHaan, L.R. 2006. Prospects for developing perennial grain crops. Bioscience 56:649-659.

276 DeHaan, L.R., Van Tassel, D.L. and Cox, T.S. 2005. Perennial grain crops: a synthesis of ecology and plant breeding. Renewable Agriculture and Food Systems 20:5-14.

277 Van Tassel, D.L., DeHaan, L.R. and Cox, T.S. 2010. Missing domesticated plant forms: can artificial selection fill the gap? Evolutionary Applications 3(5-6):434-452. 
278 Scheinost, P.L., Lammer, D.L., Cai, X., Murray, T.D., and Jones, S.S. 2001. Perennial wheat: a sustainable cropping system for the Pacific Northwest. American Journal of Alternative Agriculture 16:147-151.

279 Murphy, K., Lyon, S., Balow, K., and Jones, S. 2009. Postsexual cycle regrowth and grain yield in Thinopyrum elongatum $\times$ Triticum aestivum amphiploids. Plant Breeding 129:480-483.

280 Loeppky, H.A., Horton, P.R., Bittman, S., Townley-Smith, L., Wright, T., and Nuttall, W.F. 1999. Forage seed yield response to $\mathrm{N}$ and $\mathrm{P}$ fertilizers and soil nutrients in northeastern Saskatchewan. Canadian Journal of Soil Science 79:265-271.

281 Naylor, R.L., Liska, A.J., Burke, M.B., Falcon, W.P., Gaskell, J.C., Rozelle, S.D., and Cassman, K.G. 2007. The ripple effect: biofuels, food security, and the environment. Environment 49:30-43.

282 Fargione, J., Hill, J., Tilman, D., Polasky, S., and Hawthorne, P. 2008. Land clearing and the biofuel carbon debt. Science 31:1235-1238.

283 Searchinger, T., Heimlich, R., Houghton, R.A., Dong, F., Elobeid, A., Fabiosa, J., Tokgoz, S., Hayes, D., and $\mathrm{Yu}$, T.-H. 2008. Use of US croplands for biofuels increases greenhouse gases through emissions from land-use change. Science 319:1238-1240.

284 Adler, P.R., del Grosso, S.J., and Parton, W.J. 2007. Life-cycle assessment of net greenhouse gas flux for bioenergy cropping systems. Ecological Applications 17:675-691.

285 Heaton, E., Voigt, T., and Long, S.P. 2004. A quantitative review comparing the yields of two candidate $\mathrm{C}-4$ perennial biomass crops in relation to nitrogen, temperature and water. Biomass and Bioenergy 27:21-30.

286 Lewandowski, I., Scurlock, J.M.O., Lindvall, E., and Christou, M. 2003. The development and current status of perennial rhizomatous grasses as energy crops in the US and Europe. Biomass and Bioenergy 25:335-361.

287 McLaughlin, S.B. and Kszos, L.A. 2005. Development of switchgrass (Panicum virgatum) as a bioenergy feedstock in the United States. Biomass and Bioenergy 28:515-535.

288 Schmer, M.R., Vogel, K.P., Mitchell, R.B., and Perrin, R.K. 2008. Net energy of cellulosic ethanol from switchgrass. Proceedings of the National Academy of Sciences of the United States of America 105:464-469.

289 Volk, T.A., Verwijst, T., Tharakan, P.J., Abrahamson, L.P., and White, E.H. 2004. Growing fuel: a sustainability assessment of willow biomass crops. Frontiers in Ecology and the Environment 2:411-418.

290 Goldemberg, J. 2006. The ethanol program in Brazil. Environmental Research Letters 1(1): 014008.

291 Raghu, S., Anderson, R.C., Daehler, C.C., Davis, A.S., Wiedenmann, R.N., Simberloff, D., and Mack, R.N. 2006. Adding biofuels to the invasive species fire? Science 313:1742-1742.

292 Lal, R. 2005. Effects of plant species richness on invasion dynamics, disease outbreaks, insect abundances and diversity. Environment International 31:575-584.

293 Wilhelm, W.W., Johnson, J.M.F., Hatfield, J.L., Voorhees, W.B., and Linden, D.R. 2004. Crop and soil productivity response to corn residue removal: a literature review. Agronomy Journal 96:1-17.
294 Frank, A.B., Berdahl, J.D., Hanson, J.D., Liebig, M.A., and Johnson, H.A. 2004. Biomass and carbon partitioning in switchgrass. Crop Science 44:1391-1396.

295 Parrish, D.J. and Fike, J.H. 2005. The biology and agronomy of switchgrass for biofuels. Critical Reviews in Plant Sciences 24:423-459.

296 Zenone, T., Chen, J., Deal, M., Wilske, B., Xu, J., Bhardwaj, A.K., Hamilton, S.K., and Philip, R.G. 2011. $\mathrm{CO}_{2}$ fluxes of transitional bioenergy crops: effect of land conversion during the first year of cultivation. Global Change Biology-Bioenergy 3:401-412.

297 Anex, R.P., Lynd, L.R., Laser, M.S., Heggenstaller, A.H., and Liebman, M. 2007. Potential for enhanced nutrient cycling through coupling of agricultural and bioenergy systems. Crop Science 47:1327-1335.

298 Lehmann, J. 2007. Bio-energy in the black. Frontiers in Ecology and the Environment 5:381-387.

299 Jordan, N., Boody, G., Broussard, W., Glover, J.D., Keeney, D., McCown, B.H., McIsaac, G., Muller, M., Murray, H., Neal, J., Pansing, C., Turner, R.E., Warner, K., and Wyse, D. 2007. Sustainable development of the agricultural bioeconomy. Science 316:1570 1571.

300 Bhardwaj, A.K., Zenone, T., Jasrotia, P., Robertson, G.P., Chen, J., and Hamilton, S.K. 2011. Water and energy footprints of bioenergy crop production on marginal lands. Global Change Biology Bioenergy 3:208-222.

301 Xie, M., Zhou, F., Yang, Y.H., and Lu, X. 2008. A summary of ecological and energy-producing effects of perennial grasses. Acta Ecological Sinica 28:2329-2342.

302 Chen, Y. 2003. Medicines from wild plants in Helongjiang. Quarterly of Forest By-product and Specialty in China 2:50-53.

303 Song, Y., Gu, J.M., and Liu, X. 2009. The status of development and utilization of Chinese medicine resources and countermeasures on sustainable development. Chinese Archives of Traditional Chinese Medicine 27:86-87.

304 Hall, J.B., Tomlinson, H.F., Oni, P.I., Buchy, M., and Aebischer, D.P. 1997. Parkia biglobosa. A Monograph. School of Agricultural and Forest Sciences. University of Wales, Bangor, UK.

305 Ouedraogo, A.S. 1995. Parkia biglobosa (Leguminosae) en Afrique de l'Ouest: Biosystématique et amélioration. Institute for Forestry and Nature Research IBN-DLO, Wageningen, The Netherlands. p. 74-75.

306 Jackson, R.B., Jobbagy, E.G., and Nosetto, M.D. 2009. Ecohydrology in a human-dominated landscape. Ecohydrology 2:383-389.

307 Chan, K.M.A. and Daily, G.C. 2008. The payoff of conservation investments in tropical countryside. Proceedings of the National Academy of Sciences of the United States of America 105:19342-19347.

308 Carpenter, S.R. and Folke, C. 2006. Ecology for transformation. Trends in Ecology and Evolution 21:309-315.

309 Farber, S., Costanza, R., Childers, D.L., Erickson, J., Gross, K., Grove, M., Hopkinson, C.S., Kahn, J., Pincetl, S., Troy, A., Warren, P., and Wilson, M. 2006. Linking ecology and economics for ecosystem management. BioScience 56:121-133.

310 Pascual, U. and Perrings, C. 2007. Developing incentives and economic mechanisms for in situ biodiversity 
conservation in agricultural landscapes. Agriculture Ecosystems and Environment 121:256-268.

311 Salzman, J. 2005. Creating markets for ecosystem services: notes from the field. New York University Law Review 80:870-961.

312 Robertson, M.M. 2006. The nature that capital can see: science, state, and market in the commodification of ecosystem services. Environment and Planning D: Society and Space 24:367-387.

313 Secchi, S., Tyndall, J., Schulte, L.A., and Asbjornsen, H. 2008. High crop prices and conservation: raising the stakes. Journal of Soil and Water Conservation 63:69-73.

314 Mas, J.F. 1999. Monitoring land-cover changes: a comparison of change detection techniques. International Journal of Remote Sensing 20:139-152.

315 Rice, P.D. and McLean, J. 1999. Sustainable Coffee at the Crossroads. The Consumer's Choice Council, Washington, DC.

316 Cole, R.J. 2010. Social and environmental impacts of payments for environmental services for agroforestry on small-scale farms in southern Costa Rica. International Journal of Sustainable Development and World Ecology 17:208-216.

317 Munoz Pina, C. and Avila Forcada, S. 2004. Effects of an environmental tax on pesticides in Mexico. Industry and Environment 27:33-36.

318 Quintero, M., Wunder, S., and Estrada, R.D. 2009. For services rendered? Modeling hydrology and livelihoods in Andean payments for environmental services schemes. Forest Ecology and Management 258:1871-1880.

319 Ebeling, J. and Yasue, M. 2008. Generating carbon finance through avoided deforestation and its potential to create climatic, conservation and human development benefits. Philosphical Transactions of the Royal Society 363:1917-1924.

320 Gallai, N., Salles, J.M., Settele, J., and Vaissiére, B.E. 2009. Economic valuation of the vulnerability of world agriculture confronted to pollinator decline. Ecological Economics 68:810-821.

321 Corbera, E., Kosoy, N., and Martínez-Tuna, M. 2007. The equity implications of marketing ecosystem services in protected areas and rural communities: case studies from meso-America. Global Environmental Change 17:365-380.

322 Anderies, J.M., Ryan, P., and Walker, B.H. 2006. Loss of resilience, crisis, and institutional change: lessons from an intensive agricultural system in southeastern Australia. Ecosystems 9:865-878.

323 Tompkins, E.L. and Adger, W.N. 2004. Does adaptive management of natural resources enhance resilience to climate change? Ecology and Society 9(2):10.

324 Walker, B., Hollin, C.S., Carpenter, S.R., and Kinzig, A. 2004. Resilience, adaptability and transformability in social-ecological systems. Ecology and Society $9(2): 5$. 